\title{
Antagonism between RSF1 and SR proteins for both splice-site recognition in vitro and Drosophila development
}

\author{
Emmanuel Labourier, ${ }^{1,5}$ Henri-Marc Bourbon, ${ }^{2,5}$ Imed-eddine Gallouzi, ${ }^{1,3}$ Maggy Fostier, ${ }^{2,4}$ \\ Eric Allemand, ${ }^{1}$ and Jamal Tazi ${ }^{1,6}$ \\ ${ }^{1}$ Institut de Génétique Moléculaire, Centre National de la Recherche Scientifique (CNRS), F34293 Montpellier Cedex 5, \\ France; ${ }^{2}$ Centre de Biologie du Développement, CNRS, Université Paul Sabatier, F31062 Toulouse, France
}

\begin{abstract}
Specific recognition of splice sites within metazoan mRNA precursors (pre-mRNAs) is a potential stage for gene regulation by alternative splicing. Splicing factors of the SR protein family play a major role in this regulation, as they are required for early recognition of splice sites during spliceosome assembly. Here, we describe the characterization of RSF1, a splicing repressor isolated from Drosophila, that functionally antagonizes SR proteins. Like the latter, RSF1 comprises an amino-terminal RRM-type RNA-binding domain, whereas its carboxy-terminal part is enriched in glycine (G), arginine (R), and serine (S) residues (GRS domain). RSF1 induces a dose-sensitive inhibition of splicing for several reporter pre-mRNAs, an inhibition that occurs at the level of early splicing complexes formation. RSF1 interacts, through its GRS domain, with the RS domain of the SR protein SF2/ASF and prevents the latter from cooperating with the U1 small nuclear ribonucleoprotein particle (U1 snRNP) in binding pre-mRNA. Furthermore, overproduction of RSF 1 in the fly rescues several developmental defects caused by overexpression of the splicing activator SR protein B52/ SRp55. Therefore, RSF1 may correspond to the prototypical member of a novel family of general splicing repressors that selectively antagonize the effect of SR proteins on 5' splice-site recognition.
\end{abstract}

[Key Words: pre-mRNA splicing; RNA-binding proteins; SF2/ASF; U1 snRNP; RSF1; B52/SRp55]

Received September 25, 1998; revised version accepted January 28, 1999.

Pre-mRNA splicing is an essential step in the expression of most metazoan protein-coding genes, often regulated in a cell-type specific or developmental manner. The precision and efficiency of the splicing reaction result from a dynamic series of interactions among the U1, U2, U4/ U6, and U5 small nuclear ribonucleoprotein (snRNP) particles, non-snRNPs, and the pre-mRNA that lead to the formation of the spliceosome, the ribonucleoprotein structure in which the accurate excision of intervening sequences (introns) takes place (Sharp 1994; Krämer 1996; Staley and Guthrie 1998). Although most of the biochemical events involved in constitutive pre-mRNA splicing are being elucidated, the complex regulation underlying the selection of alternative exons is less well understood (Adams et al. 1996; Wang and Manley 1997). Both structural features and sequence content of premRNAs appear to be involved (Green 1991). In the past

Present addresses: ${ }^{3}$ Howard Hughes Medical Institute, Yale University School of Medicine, New Haven, Connecticut 06536-0812 USA; ${ }^{4}$ Department of Biological Sciences, University of Manchester, Manchester, M13 9PT, UK.

${ }^{5}$ These authors have contributed equally to this work.

${ }^{6}$ Corresponding author.

E-MAIL tazi@igm.cnrs-mop.fr; FAX (33) 0467040245. few years, a class of purine-rich exonic elements known as exonic splicing enhancers (ESEs) has been identified in a number of pre-mRNAs (Katz and Skalka 1990; Lavigueur et al. 1993; Sun et al. 1993a,b; Watakabe et al. 1993; Xu et al. 1993; Caputi et al. 1994; Dirksen et al. 1994, 1995; Tanaka et al. 1994; Ramchatesingh et al. 1995; Staffa and Cochrane 1995; Staffa et al. 1997). These sequences are likely to play a critical role in the initial recognition and pairing of the $5^{\prime}$ and $3^{\prime}$ splice sites (Tian and Maniatis 1993; Staknis and Reed 1994; Berget 1995). They are expected to bind a set of RNA-binding proteins among which several members of the SR protein family are known to influence the splice site choice (Lavigueur et al. 1993; Sun et al. 1993b; Staknis and Reed 1994; Fu 1995; Manley and Tacke 1996; Liu et al. 1998).

Members of the highly conserved SR protein family of splicing regulators (Zahler et al. 1992; Fu 1995; Manley and Tacke 1996), including SRp20/X16/RBP1, SF2/ASF (SRp30a), SC35 (SRp30b), and B52/SRp55 have modular structures that consist of one or two RNA-recognition motifs (RRMs) and a carboxy-terminal arginine (R)/serine (S)-rich domain (the so-called RS domain). They are thought to be essential splicing factors, as SR proteins individually can complement splicing-deficient cytoplasmic S100 extracts, which lack SR proteins but con- 
tain all other factors necessary for splicing (Ge et al. 1991; Krainer et al. 1991; Mayeda et al. 1992; Zahler et al. 1992; Cavaloc et al. 1994). Both the RRM and the RS domains are essential for the function of SR proteins as splicing factors (Zamore et al. 1992; Càceres and Krainer 1993; Zuo and Manley 1993; Wang et al. 1998). The RS domain is responsible for specific protein-protein interactions among RS domain-containing proteins (Wu and Maniatis 1993; Amrein et al. 1994; Kohtz et al. 1994; Zuo and Maniatis 1996), interactions thought to constitute a bridge between $5^{\prime}$ and $3^{\prime}$ splice sites during splicesite selection. Such protein contacts promote the binding of U1 snRNP to the $5^{\prime}$ splice site and U2 snRNP auxiliary factor $65-\mathrm{kD}$ subunit $\left(\mathrm{U}_{2} \mathrm{AF}^{65}\right)$ to the $3^{\prime}$ splice site at earliest stages of spliceosome assembly (Staknis and Reed 1994; Reed 1996). At least where introns with weak 3' splice sites are involved, binding of SR proteins to an ESE may facilitate 3' splice-site complex formation through interaction with U2AF (Zuo and Maniatis 1996).

Many of the SR proteins described previously can affect usage of alternative $5^{\prime}$ or $3^{\prime}$ splice sites in a concentration-dependent manner (Ge and Manley 1990; Krainer et al. 1990; Tian and Maniatis 1993; Zahler et al. 1993; Càceres et al. 1994; Reed 1996). Both in vitro and in vivo, a small increase in the concentration of SF2/ASF prevents the inappropriate exon-skipping of certain premRNAs (Mayeda and Krainer 1992; Mayeda et al. 1993). It has been shown also that high levels of SF2/ASF regulate alternative splicing by promoting the use of proximal versus distal 5' splice sites (Ge and Manley 1990; Krainer et al. 1990). Additionally, targeted disruption of SF2/ASF in chicken cells demonstrated that SF2/ASF is required for viability, and this depletion of SF2/ASF affects splicing of specific transcripts in vivo (Wang et al. 1996; Wang and Manley 1997). Similarly, mutants of the B52 gene are homozygous lethal in Drosophila (Ring and Lis 1994) and overexpression of the B52/SRp55 protein causes severe phenotypes (Kraus and Lis 1994). Therefore, the relative abundance of each SR protein and/or the molar ratio of each SR protein to selective antagonists may determine the patterns of alternative splicing of many genes expressed in a particular cell type. In agreement with this, it has been observed that the relative amount of individual SR proteins varies in different tissues (Zahler et al. 1993). As an example, the expression of mouse $X 16$ mRNA is high in thymus, spleen, and testes but is low or undetectable in liver, kidney, brain, and heart (Zahler et al. 1993). Similarly, variable levels of X16 and SC35 mRNAs are expressed in different cell lines and stages of development (Ayane et al. 1991; Vellard et al. 1992). The finding that competing levels of the heterogeneous nuclear ribonucleoprotein (hnRNP) particle protein A1 could have opposing effects on SF2/ASF (Mayeda and Krainer 1992; Mayeda et al. 1993; Càceres et al. 1994) led to the suggestion that the regulation of the expression of a wide variety of genes by alternative splicing may be accomplished at least in part by variation in the nuclear concentration of antagonistic splicing factors. Identification and characterization of splicing factors that counteract SR proteins may therefore be an important step in understanding the mechanism for regulation of gene expression by alternative splicing.

By adopting an oligonucleotide-directed molecular approach to seek for RNA-binding proteins possibly involved in important developmental decisions, we have identified three novel D. melanogaster RRM superfamily proteins previously [referred to as Rox proteins (Brand et al. 1995)], among which Rox21, renamed here RSF1 (for repressor splicing factor 1 ), exhibits extensive sequence identity $(54 \%-58 \%)$ in its single amino-terminal RRM with members of the SR protein family. RSF1 also possesses a carboxy-terminal domain enriched in glycine (G), arginine, and serine residues (GRS domain). Here we show that the latter domain mediates specific interactions with itself and with members of the SR protein family. However, in vitro complementation assays show that RSF1 inhibits splicing of several reporter premRNAs, an inhibition that can be selectively counteracted by purified SR proteins. These studies, together with the finding that RSF1 acts as an SR protein antagonist in vivo, represent the first identification of a general splicing repressor.

\section{Results \\ RSF1 inhibits splicing by competing with the SR proteins}

The structural features of RSF1, its nuclear localization, and association with a subset of actively transcribed regions of giant polytene chromosomes (data not shown) prompted us to seek a role of this protein in pre-mRNA splicing. Our initial attempts to do this were based on complementation experiments using a HeLa nuclear extract containing a low level of SR proteins, knowing that RSF1 fails to have the ability of SR protein to restore the splicing activity of the S100 extract (data not shown). To assess the effect of RSF1 on pre-mRNA splicing, we first used a model $\beta$-globin pre-mRNA substrate $(\beta-3 \mathrm{~A} 1)$ that has three copies of a high-affinity binding site for RSF1 established by SELEX analysis (E. Labourier, E. Allemand, S. Brand, M. Fostier, J. Tazi, and H.-M. Bourbon, unpubl.), inserted 20 bases downstream of the first intron of $\beta$-globin. This reporter pre-mRNA substrate was spliced efficiently in a HeLa nuclear extract (Fig. 2A, lanes 2,14, below). However, when this preparation of HeLa nuclear extract was supplemented with an excess of purified recombinant glutathione $S$-transferase (GST)RSF1 fusion protein produced in Escherichia coli (Fig. 1, lane 3), splicing was readily inhibited in a dose-dependent manner (Fig. 2A, lanes 3,4). One trivial explanation, that the recombinant protein preparation contained a component that inhibited splicing, could be eliminated, because GST alone (Fig. 1, lane 1) prepared under the same conditions had no effect on splicing (Fig. 2A, lanes $11,12)$. No inhibition was observed either with heat-denatured GST-RSF1 (data not shown) or two truncated versions of the protein in which the GRS or the RRM domain was selectively removed (Figs. 1, lanes 4,5, and 2A, lanes 5-8). This result demonstrates a requirement 
Figure 1. Schematic representation of the recombinant proteins used in this study (Left). RNA recognition motifs (gray), GRS and RS domains (white), and hexahistidine tags (black) are boxed. GST fusion proteins were expressed and purified as described (Materials and Methods). SRp30 protein was purified from calf thymus as described (Zahler et al. 1992). Around $1 \mu \mathrm{g}$ of each purified protein was analyzed on a $12 \%$ SDS-polyacrylamide gel and stained with Coomassie blue (right). Markers $70 \mathrm{~K}, \mathrm{~A}, \mathrm{~B}, \mathrm{~B}^{\prime}$, and $\mathrm{D}$ refer to $\mathrm{U} 1$ snRNP proteins. (M) Molecular weight markers.

for native protein conformation, as well as for the joint presence of the RRM and the GRS domain, for the inhibition of splicing. Furthermore, as the GRS-truncated version (GST-RSF1 $\Delta$ C) binds RNA in vitro (E. Labourier, E. Allemand, S. Brand, M. Fostier, J. Tazi, and H.-M. Bourbon, unpubl.), this joint requirement indicates that splicing inhibition is not caused by mere nonspecific binding to pre-mRNA. Additionally, because RSF1 and Drosophila SR protein RBP1 (Kim et al. 1992) have homologous RRMs and similar size, we tested the effect of complementing HeLa nuclear extract with purified GST-RBP1 (Fig. 1, lane 2). This protein had no detectable effect (Fig. 2A, lanes 9,10), even though it binds RNA in vitro (data not shown). Furthermore, GST-RSF1 inhibits splicing of $\beta$-globin pre-mRNA, which does not contain high-affinity RSF1 binding sites (Fig. 2B, lanes 3,4), implying that its splicing inhibition activity in vitro is not likely to be restricted to reporter pre-mRNAs containing RSF1-selected sequences. Using native gel electrophoresis to isolate splicing complexes, we were able to show that the inhibition was at the level of spliceosome assembly (data not shown). Taken together, our results support the idea that the inhibition of splicing by GSTRSF1 is related directly to its function as a general splicing repressor that acts at an early stage of spliceosome assembly.

Interestingly, a mixture of purified SR proteins (data not shown) or purified SRp30 (Fig. 1, lane 6; note that SRp30 contains both SF2/ASF and SC35 proteins) restored full splicing activity of the RSF1-inhibited HeLa nuclear extract in a concentration-dependent manner (Fig. 2, A, lanes 16 and 17, and B, lanes 10 and 11). Comparison with known amounts of purified SRp30 indicated that our preparation of HeLa nuclear extract contained $\sim 5$ pmoles (110 ng) of SRp30 per microliter of extract. The concentration of GST-RSF1 required to achieve complete inhibition of splicing was almost identical (6 pmoles per microliter of extract). A similar quantity of SRp30 was used to restore full splicing activity, suggesting that RSF1 might proceed by competing with SR proteins for the same function.

\section{RSF1 prevents E-complex formation in vitro}

The SR proteins are known to promote the earliest stages of the spliceosome assembly involving the formation of

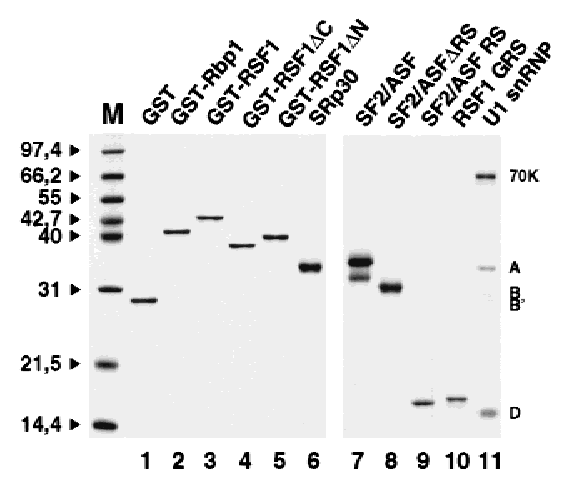

the E (for early) or commitment complex, in which the 5' splice site is recognized by U1 snRNP and the 3' splice
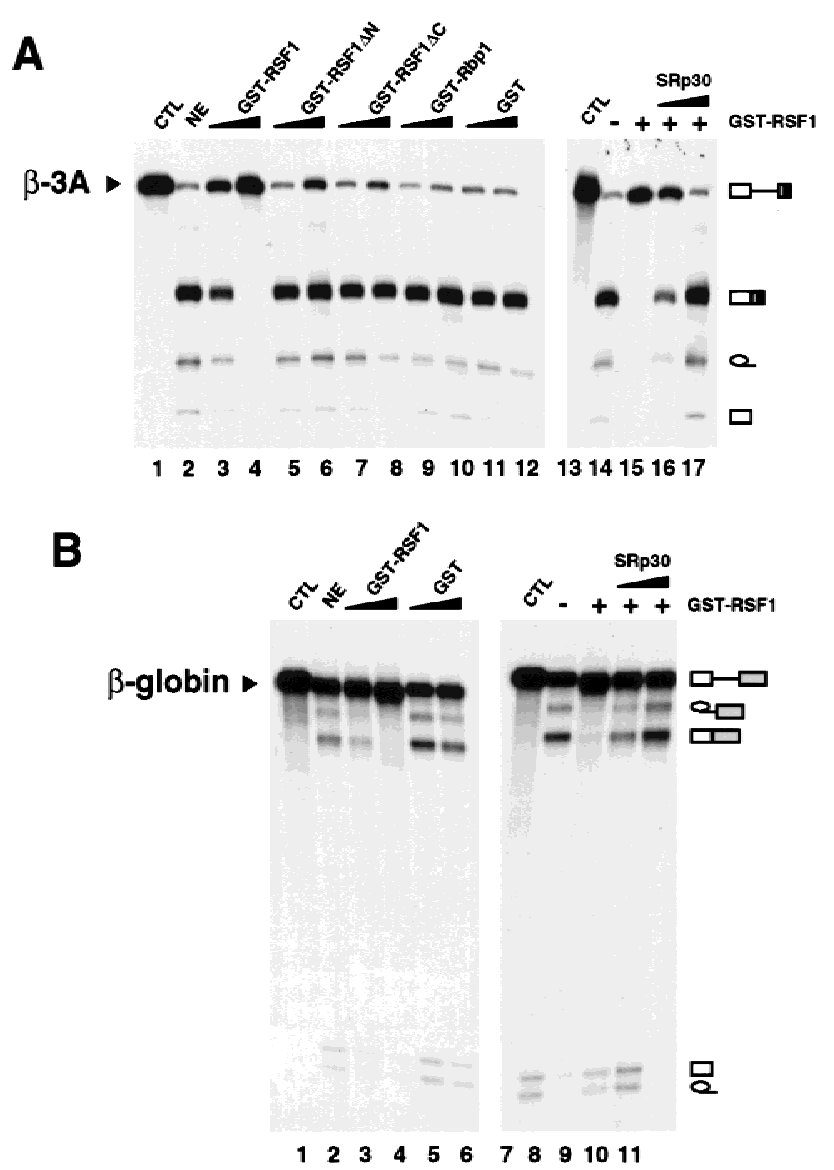

Figure 2. The effect of GST-RSF1 on pre-mRNA splicing in vitro. (A) $\beta$-3A splicing inhibition by GST-RSF1 is relieved by purified SRp30. ${ }^{32} \mathrm{P}$-Labeled $\beta$-3A pre-mRNA (50 pmoles, lanes $1,13)$ were incubated in HeLa cell nuclear extract (NE) under splicing conditions without (lanes 2,14) or with 18 or 36 pmoles of the indicated recombinant proteins (lanes 3-12). HeLa nuclear extract inhibited by 36 pmoles of GST-RSF1 (lane 15) was complemented with 15 or 30 pmoles of purified SRp30 (lanes 16,17). Splicing products (depicted at right) were analyzed on a $7 \%$ denaturing polyacrylamide gel and revealed by autoradiography. (B) Splicing reactions (lanes 1-11) were performed as in $A$ (lanes 1-4 and $11-17$, respectively) using a $\beta$-globin premRNA lacking the RSF1 high-affinity binding sites. 
site by binding of $\mathrm{U}_{2} \mathrm{AF}^{65}$ at the pyrimidine tract (Ruskin et al. 1988; Zamore and Green 1989; Jamison et al. 1992; Michaud and Reed 1993; Staknis and Reed 1994; Reed 1996). Given that RSF1 acts as a splicing repressor of several reporter pre-mRNAs, including AdML (data not shown), a model pre-mRNA derived from the adenovirus major late-transcription unit, we tested whether it could interfere with the formation of E complex and thereby mediate splicing inhibition. Previous studies demonstrated that AdML is assembled into splicing complexes more efficiently than $\beta$-globin (Michaud and Reed 1991); we therefore used this substrate to perform E-complex assembly assays. HeLa cell nuclear extracts complemented with either purified SRp30 or GST-RSF1 were incubated with ${ }^{32} \mathrm{P}$-labeled AdML (Michaud and Reed 1991, 1993) and assembled RNP complexes were fractionated by gel filtration. As shown in Figure 3, in contrast to SRp30, which enhanced the level of E-complex assembly (Fig. 3, cf. I and III). GST-RSF1 blocked the formation of this complex completely (panels I and II). However, full E-complex assembly could be restored upon addition of competing amounts of purified SRp30 to RSF1-inhibited nuclear extract (data not shown), demonstrating that the inhibition of splicing by RSF1 was at the level of E-complex assembly.

To evaluate the effects of RSF1 on $5^{\prime}$ or $3^{\prime}$ splice-site selection, specific complexes were assembled independently on RNAs containing only a $3^{\prime}$ or 5 ' splice site, respectively, as described (Michaud and Reed 1993). In agreement with previous studies, both AdML 5' and 3' half substrates (panels IV and VI, respectively) gave rise to discrete peaks in the position of E complex when incubated with HeLa nuclear extract. Although substantial E complex on the $3^{\prime}$ splice site was still detected in extracts complemented with GST-RSF1 (panel VII, 3.5 pmoles/microliter of extract), little or no E complex was formed on the $5^{\prime}$ splice site (panel V). Inhibition of $\mathrm{E}$ complex formation on the $5^{\prime}$ splice site is unlikely to result from unspecific binding of GST-RSF1 to AdML 5' half substrate because neither truncated versions of RSF1 nor GST-RBP1 had the same effect (data not shown). We conclude that RSF1 probably prevents the stable binding of factor(s) to the $5^{\prime}$ splice site but has only slight effect on the binding of factor(s) to the $3^{\prime}$ splice site.

\section{RSF1 impedes stable binding of U1 snRNP at the 5' splice site}

The prototypical SR protein SF2/ASF was shown previously to cooperate with the U1 snRNP particle in forming a stable complex at the $5^{\prime}$ splice site of the model pre-mRNA PIP7.A (Kohtz et al. 1994). We therefore tested whether RSF1 could destabilize the binding of U1 snRNP to the $5^{\prime}$ splice site. Different combinations of recombinant SF2/ASF, purified U1 snRNP (Fig. 1, lanes $7,11)$ and GST-RSF1 were incubated with either ${ }^{32} \mathrm{P}-1 \mathrm{a}-$ beled PIP7.A or PIP7 ${ }^{5} \mathrm{AU}$, a mutant version that is identical to PIP7.A, except that the invariant GU dinucleotide at the $5^{\prime}$ splice site is changed to AU (Kohtz et al. 1994; Jamison et al. 1995). The mixes were then analyzed by native gel electrophoresis to resolve the U1 snRNPcontaining complexes from the free probe. No complex was detected with the mutated substrate (Fig. 4, lane 3), indicating that an intact, functional 5 ' splice site is required for formation of U1 snRNP-SF2/ASF-pre-mRNA complex. In agreement with previous findings (Kohtz et al. 1994), U1 snRNP alone gave rise to low levels of U1 snRNP-pre-mRNA complex formation (lane 2), whereas when both U1 snRNP and SF2/ASF were incubated with the pre-mRNA a strong complex was detected (lane 5). Interestingly, GST-RSF1 had no effect on the weak binding of U1 snRNP to the pre-mRNA (lane 15) but impaired the formation of U1 snRNP-SF2/ASF-pre-mRNA
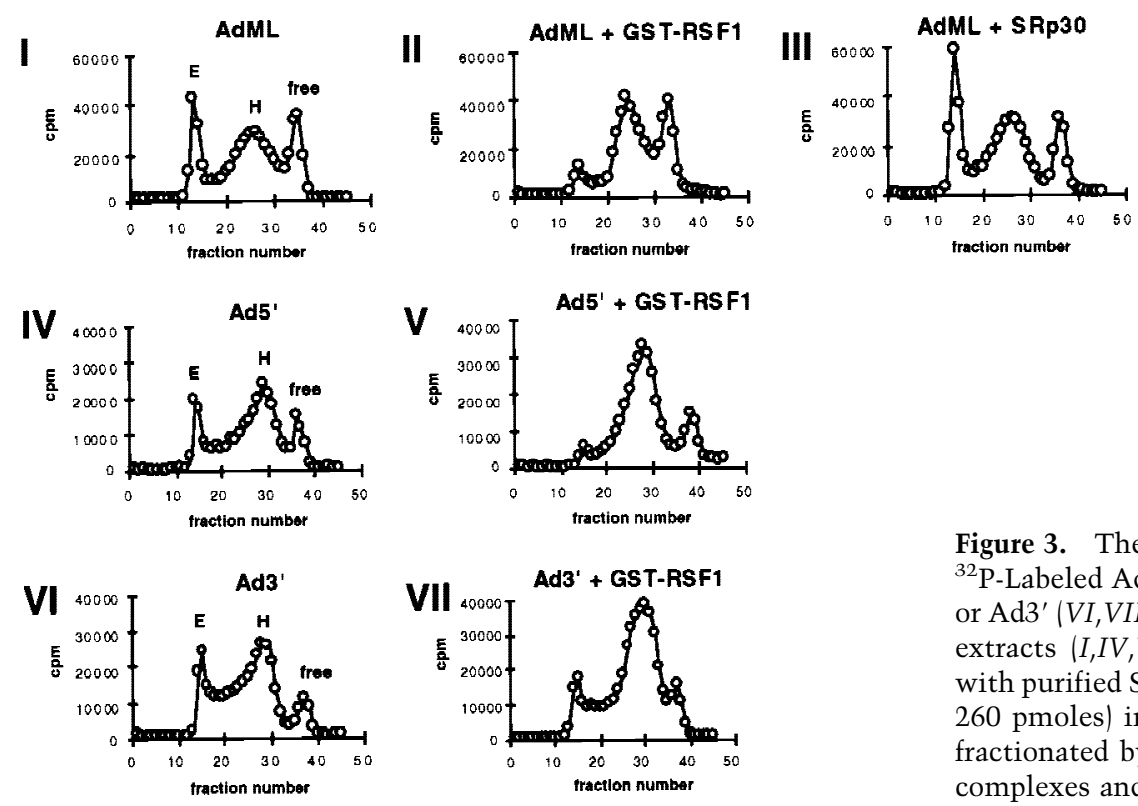

Figure 3. The effect of GST-RSF1 on E-complex assembly. ${ }^{32}$ P-Labeled AdML pre-mRNA $(I-I I I)$, truncated Ad5' $(I V, V)$, or Ad3' $(V I, V I I)$ pre-mRNAs were incubated in HeLa nuclear extracts $(I, I V, V I)$, or HeLa nuclear extracts supplemented with purified SRp30 (III; 210 pmoles) or GST-RSF1 (II,V,VII; 260 pmoles) in the absence of ATP. Complexes were then fractionated by gel filtration. The peaks containing $\mathrm{E}$ or $\mathrm{H}$ complexes and free RNA are indicated. 


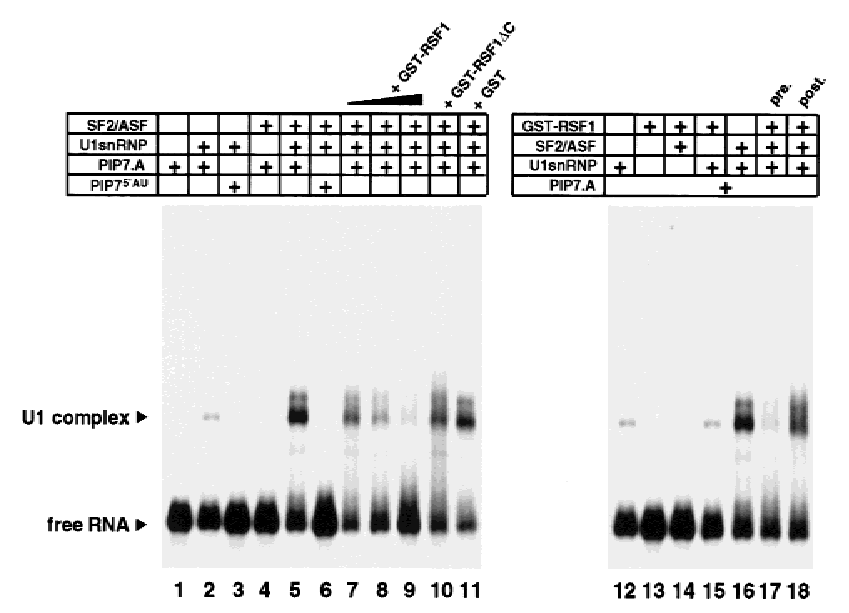

Figure 4. The effect of GST-RSF1 on U1 snRNP binding to the 5 ' splice site. U1 snRNP-SF2/ASF-pre-mRNA complex formation assays were performed as described previously (Kohtz et al. 1994) in 10- $\mu$ l reactions containing 1.7 pmole of U1 snRNP (lanes 2,3,5,6-12,15-18), 3 pmoles of SF2/ASF (lanes 4-11, 14,16-18), 0.67 pmole (lane 7), 1.35 pmole (lane 8), or 2.7 pmoles (lanes 9, 13-15,17,18) of GST-RSF1, 2.7 pmoles of GSTRSF1 $\Delta \mathrm{C}$ (lane 10), 2.7 pmoles of GST (lane 11), and 1.5 fmole of either ${ }^{32}$ P-Labeled PIP7.A (lanes $1,2,4,5,7-18$ ) or PIP7 ${ }^{5}$ AU premRNAs (lanes 3,6). GST fusion proteins and SF2/ASF were added to the reaction mixture at the same time except for the postcompetition assay (lane 18) in which GST-RSF1 was added after $\mathrm{U} 1 \mathrm{snRNP}$ and incubated for additional $5 \mathrm{~min}$ at $30^{\circ} \mathrm{C}$.

ternary complex dramatically (lanes 7-9). The GRS domain of RSF1 was required to mediate inhibition, as a GRS-truncated version of RSF1 was inactive (lane 10). The GST-RSF1 inhibition was dose dependent; it was almost complete when the ratio between RSF1 and SF2/ ASF was nearly 1:1 (lane 9). The possibility that inhibition was caused by unspecific binding of GST-RSF1 to RNA can be ruled out, because GST alone (lane 11), or GST-RSF1 $\Delta$ C (lane 10) had negligible effects on ternary complex formation. Furthermore, preassembled ternary complex was refractory to inhibition by GST-RSF1 (cf. lanes 16 and 18), suggesting a direct interaction between RSF1 and U1 snRNP and/or SF2/ASF.

\section{The GRS domain of RSF1 interacts with the RS domain of SF2/ASF}

The RS domain of SF2/ASF is required for the direct interaction between the latter and the 70K U1 snRNPspecific protein (U1-70K) and likely mediates the stable binding of U1 snRNP to the 5' splice site. Because this domain is involved in various selective protein-protein contacts (Wu and Maniatis 1993; Kohtz et al. 1994; Lynch and Maniatis 1995, 1996), we asked whether specific inhibition of 5' splice-site recognition could result from specific binding of this domain with a defined domain of RSF1. To test this, GST-RSF1 or GST-RSF1 $1 \mathrm{C}$ proteins were immobilized on glutathione-Sepharose beads and incubated with a purified His-tagged RS domain of SF2/ASF (Fig. 1, lane 9). Strikingly, the RS domain of SF2/ASF quantitatively bound to GST-RSF1 (Fig. 5A, lane 4). In contrast, only a background level of binding, similar to that for beads alone, was detected with GST-RSF1 $\Delta \mathrm{C}$ (Fig. 5A, cf. lanes 5 and 6), suggesting that the GRS domain of RSF1 is essential for binding. Interestingly, a purified His-tagged GRS domain (Fig. 1, lane 10) exhibited the same chromatographic behavior as the RS domain (Fig. 5A, lanes 1 and 2), indicating that
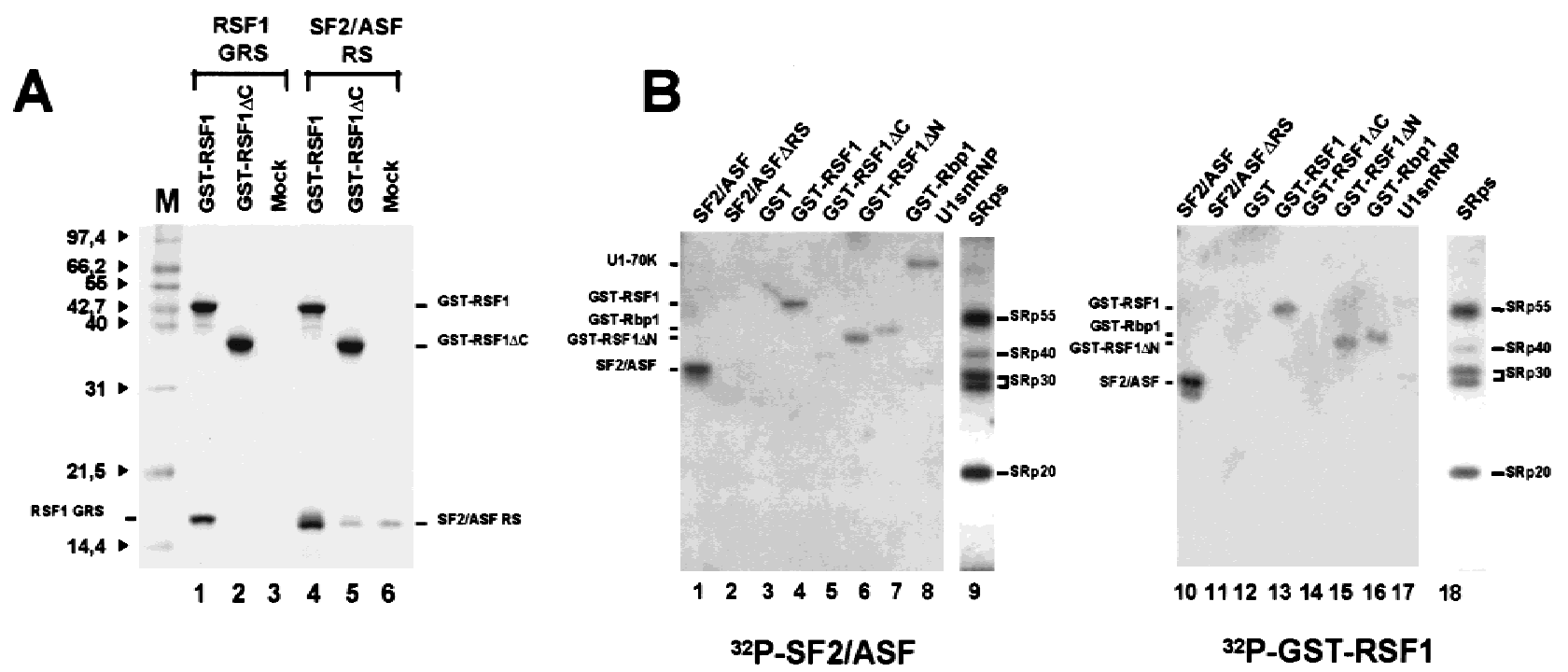

Figure 5. Physical interaction between the GRS domain of RSF1 and the RS domain of SF2/ASF. (A) GST binding assays. Purified RSF1 GRS (lanes 1-3) and SF2/ASF RS (lanes 4-6) proteins were incubated with immobilized GST-RSF1 (lanes 1,4), GST-RSF1 $\Delta$ C (lanes 2,5) or glutathione-Sepharose beads alone (lanes 3,6). Bound proteins were eluted, analyzed on $12 \%$ SDS-polyacrylamide gels, and stained with Coomassie blue. $(B)$ Far-Western analysis. The indicated proteins were separated on a $12 \%$ SDS-polycrylamide gel, transferred to nitrocellulose, renatured, and probed with ${ }^{32}$ P-labeled SF2/ASF (lanes 1-9) or GST-RSF1 (lanes 10-16). 
RSF1 not only interacts with SF2/ASF but also with itself. Given that the GRS domain is soluble at high concentrations $(10 \mathrm{mg} / \mathrm{ml})$, it seems unlikely that its interaction with itself or with the RS domain could be the result of nonspecific aggregation.

To confirm the specificity of these protein-protein interactions independently and to establish whether RSF1 could bind U1-70K, we employed Far-Western blotting (Wu and Maniatis 1993; Kohtz et al. 1994), which has been used successfully to show specific interactions between members of the SR protein family and other splicing factors. After SDS-PAGE analysis, purified proteins were transferred to filters, renatured, and probed with either ${ }^{32}$ P-labeled SF2/ASF or GST-RSF1 (Fig. 5B). The specificity of binding of modified SF2/ASF or RSF1 was confirmed by their ability to bind themselves (lanes $1,12)$, but not to truncated derivatives deleted for the RS (lanes 2,10) or GRS (lanes 5,13) domains, respectively. Although, both probes cross-reacted with immobilized SF2/ASF (lanes 1,9) and GST-RSF1 (lanes 4,12), as well as GST-RBP1 (lanes 7,15), only labeled SF2/ASF (lane 8), but not GST-RSF1 (lane 16), could decorate the U1-70K band, showing that no binding could occur between RSF1 and U1-70K. Failure to detect significant recognition between RSF1 and U1-70K provides further evidence that the observed interaction between GRS and RS domains is specific. Such an interaction is likely to compete with that occurring between SF2/ASF and U1-70K, thereby interfering with the formation of a stable complex at the 5' splice site.

\section{RSF1 functionally antagonizes the SR protein B52 in living flies}

Previous work has shown that overexpressing B52 protein, also called SRp55, in a number of cell types affects development and survival of Drosophila dramatically (Kraus and Lis 1994) and that the B52/SRp55 protein can, in vitro, regulate alternative $5^{\prime}$ splice-site choice in a concentration-dependent manner. Hence, the ratio of B52/SRp55 to other splicing factors in vivo might be an important means of regulating alternative splicing. Because developmental Northern blot (RNA) revealed that the RSF1 gene, like the B52/SRp55 gene (Champlin et al. 1991), is expressed throughout development (Fig. 6, lanes 1-11) and RSF1 interacts in vitro with B52/SRp55 (Fig. $5 \mathrm{~B}$, lane 18 ), we considered the possibility that RSF1 is such a splicing factor. Therefore, we assessed whether RSF1 might functionally antagonize the SR ptotein B52/ SRp55 in a living animal. The GAL4/UAS binary expression system (Brand et al. 1994) was used to drive prolonged high levels of expression of both RSF1 and B52/ SRp55 in a tissue-specific fashion. To this end, the wildtype RSF1 cDNA was placed within a P-element transposon under transcriptional control of the yeast GAL4-responding upstream activating sequence (UASRSF1 element) and 15 independent UAS-RSF1 transgenic lines were established, using standard procedures (Spradling and Rubin 1982). Transgenic flies carrying UAS-RSF1 and/or UAS-B52 (Kraus and Lis 1994) ele-

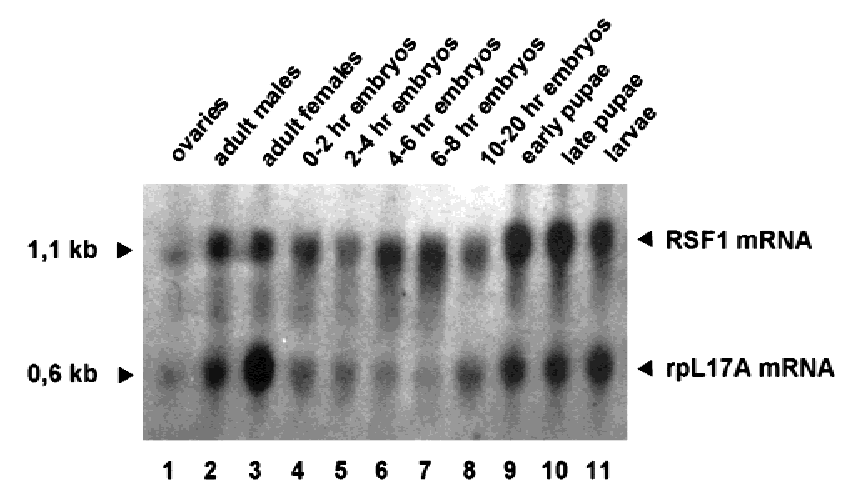

Figure 6. RSF1 mRNA expression during Drosophila development. Approximately $2 \mu \mathrm{g}$ of poly $(\mathrm{A})^{+} \mathrm{RNA}$ isolated from whole organisms of indicated stages was separated by electrophoresis in a $1 \%$ agarose-formaldehyde gel. The size-fractionated RNAs were then blotted to a nylon membrane and probed with a radiolabeled full-length cDNA insert. The blot was re-hybridized with a radioactive probe for the $\mathrm{rpL17A}$ ribosomal protein gene (Noselli and Vincent 1992) as a loading control to estimate the relative amount of RNA loaded in each lane.

ments were mated to flies that express the yeast transcriptional activator GAL4 in a cell- or tissue-specific fashion to drive strong expression of RSF1 and/or B52/ SRp55. To examine the tissue-specific expression of GAL4 in each cross, lines carrying GAL4 elements were crossed to a transgenic line carrying the E. coli $\beta$-galactosidase-encoding gene under the control of the GAL4 activator (UAS-lacZ; Brand et al. 1994).

Using the GMR-GAL4 (for glass multimer reporter; Freeman 1996) line we directed expression and activity of RSF1 to photoreceptor cells of the developing eye. Adult progeny consistently showed retinal defects, the severity of which depended on the UAS-RSF1 transgenic line employed. Relatively weak defects of retinal development were observed with UAS-RSF1 lines 5 and 6 (Fig. 7B, cf. b and c, respectively, with a) compared to line 3 (Fig 7B, d) which gave rise to eyeless adults. Furthermore, most progeny of lines 5 and 6 were viable (see Table 1) but line 3 offspring had a strongly decreased viability $(\sim 20 \%)$. The latter observation suggests that the GMR element is not entirely eye specific, and that RSF1 overproduction in tissues other than the eye is lethal. Although it is difficult to determine the direct cause of this lethality, it might reflect differences in the levels of RSF1 ectopic expression owing to different UAS-RSF1 chromosomal insertions. On increasing the dosage of $U A S-R S F 1$ elements (genotypes GMR-GAL4/+; UAS$R S F 1^{3} / U A S-R S F 1^{6}$, and GMR-GAL4/+; UAS-RSF1\% $U A S-R S F 1^{6}$ ) no viable offspring were observed (Table 1). Furthermore, embryonic lethality was also observed when high uniform expression of RSF1 was driven by GAL4 under the constitutive daughterless $(d a)$ enhancer (data not shown). Therefore, a correlation exists between the level of RSF1 overexpression in various tissues and lethality.

Another fully penetrant phenotype was observed in the progeny of crosses between $U A S-R S F 1^{5}$ and $s c a-$ 
Figure 7. RSF1 overexpression in differentiating photoreceptor cells leads to adult eye defects, and restores developmental abnormalities caused by B52/SRp55 overexpression in the same tissue. (A) Virgin female flies carrying a P-element insert in which the GAL4 coding sequence was placed under the control of five glass binding sites (GMR enhancer) were mated to male flies carrying a single UAS-B52 or $U A S-R S F 1^{3,5, \text { or }}$, element or a combination of both. (B) Stereomicroscope views of adult compound eyes. The following genotypes are shown: GMR-GAL4/+; (a) UAS-lacZ/+, (b) GMR-GAL4/UAS-RSF15, (c) GMRGAL4/+;UAS-RSF16/+; (d) GMR-GAL4/+; $U A S-R S F 1^{3} /+$, (e) GMR-GAL4/UAS-B52, (f) GMR-GAL4/UAS-B52; UAS-RSF13/+. The control fly, overexpressed the E. coli $\beta$-galactosidase $(a)$ from an $U A S-l a c Z$ construct line (Brand et al. 1994). All progeny were raised at $22^{\circ} \mathrm{C}$. Overexpression of RSF1 in the developing retina results in a decrease of adult eye size that can be moderate $(b, c)$ or severe $(d)$ depending on the site of chromosomal integration of the transgene. $(C)$ Detection of RSF1 and B52 transgene expression in single and double insert lines. (I) Determination of semiquantitative conditions to amplify UAS-RSF1, UASB52, and the Drosophila retrotransposon copia mRNAs by RT-PCR. For each experiment, $1 / 40$ (lanes $1,4,7), 1 / 20(2,5,8)$ or $1 / 10$ $(3,6,9)$ of the RT reaction performed with 5 $\mu \mathrm{g}$ of total RNAs, from larvae overexpressing both UAS-RSF1 and UAS-B52, were used for PCR amplification with the appropriate pair of specific oligonucleotides (Materials and Methods). Amplified fragments (423, 355, or 228 bp for UAS-RSF1, UAS$B 52$, and copia, respectively) were revealed by autoradiography. (M) Molecular weight markers. (II) PCR products obtained with $1 / 10$ of RT reactions performed with total RNAs from control larvae (lane 1), larvae overexpressing UAS-RSF1 (lane 2), UAS$B 52$ (lane 3), or both transgenes (lane 4). (III) Total proteins from the same transgenic larvae in $I I$, (lanes 1-4) or from HeLa nuclear extract (lane 5) were subjected to Western blot analysis using the monoclonal antibody $\mathrm{mAb} 104$. SR protein species are indicated at right.
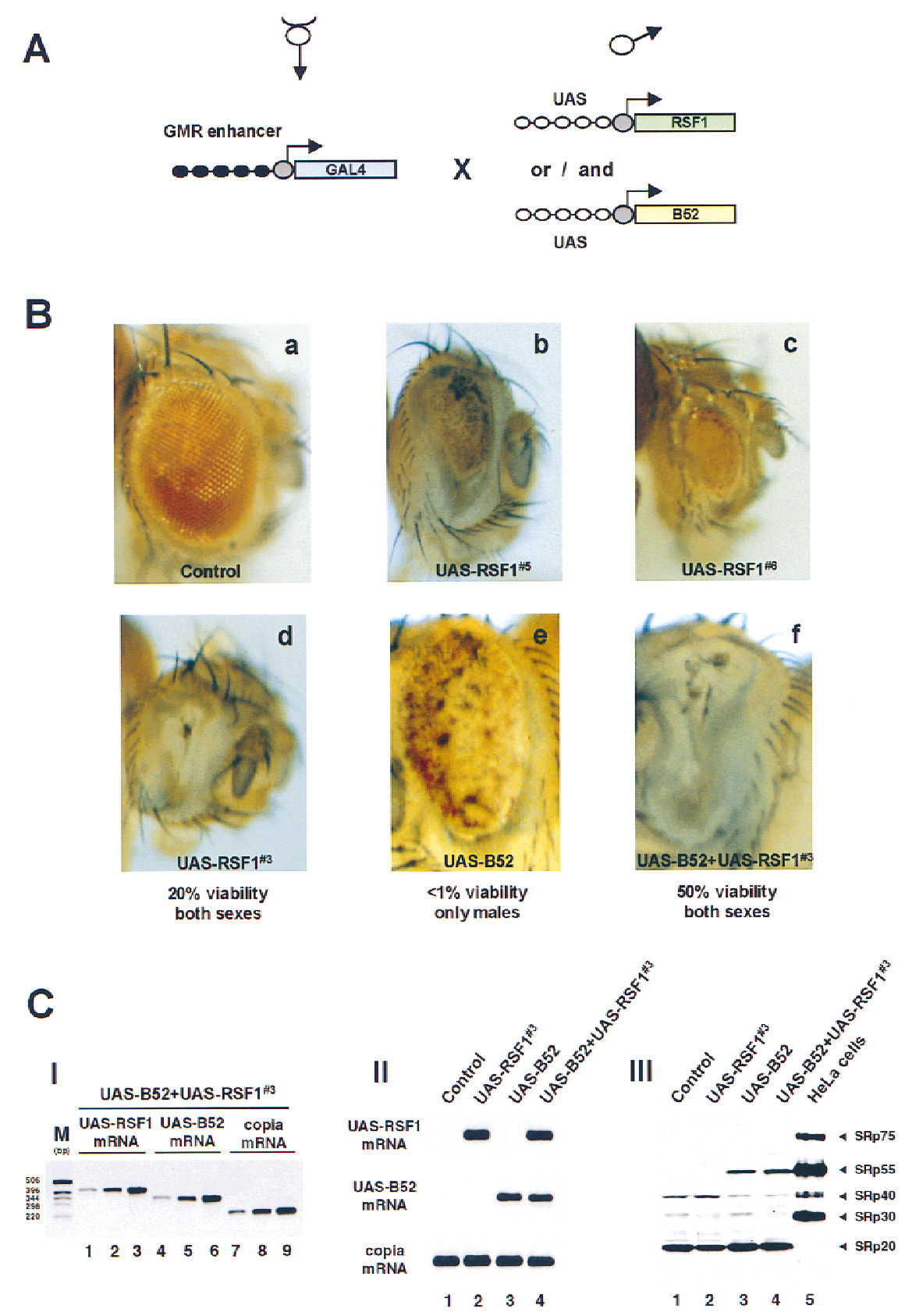

GAL4, a GAL4-expressing line that accumulates GAL4 activator in precursor cells of all sensory organs owing to an imaginal disc-specific enhancer of the scabrous gene (Y.N. Jan, unpubl.; see Fig. 8A for structure). The adult progeny displayed complete loss of all bristles (Fig. 8B, cf. $a$ and c). Increasing temperature appears to enhance the transcriptional activation by GAL4 in Drosophila (Brand et al. 1994). On elevating the level of overexpression of RSF1 by raising the offspring at higher temperatures $\left(22^{\circ} \mathrm{C}, 25^{\circ} \mathrm{C}\right.$, or $\left.28^{\circ} \mathrm{C}\right)$, the same phenotypes were aggra- vated (data not shown). Note also that mating sca-GAL4 with $U A S-R S F 1^{6}$ gave rise to progeny with late pupal lethality (Table 1).

A previous study concluded that overexpressing B52/ SRp55 protein provokes a dominant lethality (Kraus and Lis 1994). Hence, we decided to examine the phenotypic consequences of overexpressing B52/SRp55 under the same genetic background used for RSF1 overproduction. Among progeny raised at $22^{\circ} \mathrm{C}$, no adult female was observed when B52/SRp55 overexpression was driven by 
Table 1. Phenotypes of progeny from crosses between UAS-RSF1 and/or UAS-B52 transgenic lines and GAL4 lines

\begin{tabular}{|c|c|c|}
\hline Genotype of examined progeny ${ }^{a}$ & $\begin{array}{c}\text { Temperature } \\
\left({ }^{\circ} \mathrm{C}\right)\end{array}$ & Observed phenotypes \\
\hline $\begin{array}{l}U A S-R S F 1^{3,5, \text { or } 6 /+} \\
U A S-B 52 /+ \\
\text { any GAL4 driver/+ } \\
\text { GMR-GAL4/+; UAS-1acZ/+ } \\
\text { UAS-lacZ/sca-GAL4 }\end{array}$ & $\begin{array}{c}18 \text { or } 22 \\
18 \text { or } 22 \\
18 \text { or } 22 \\
22 \\
18\end{array}$ & $\begin{array}{l}\text { adults without apparent abnormalities } \\
\text { adults without apparent abnormalities } \\
\text { adults without apparent abnormalities } \\
\text { adults without apparent abnormalities } \\
\text { adults without apparent abnormalities }\end{array}$ \\
\hline \multicolumn{3}{|l|}{ Transgenic flies overexpressing RSF1 } \\
\hline 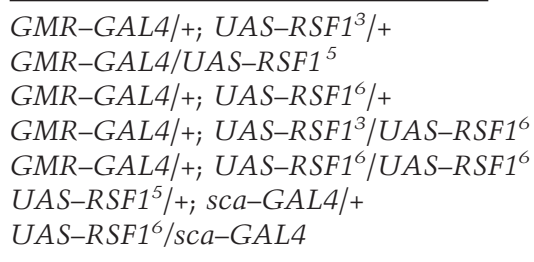 & $\begin{array}{l}22 \\
22 \\
22 \\
22 \\
22 \\
18 \\
18\end{array}$ & $\begin{array}{l}\text { some adults without retina ( } 20 \% \text { viability) } \\
\text { adults with weak retina defects ( } 100 \% \text { viability) } \\
\text { adults with weak retina defects ( } \sim 5 \% \text { viability) } \\
\text { larval and pupal lethality; no adults } \\
\text { pupal semilethality. Rare adults without retina (<1\% viability) } \\
\text { bristleless adults ( } 50 \% \text { viability) } \\
\text { late pupal stage lethality; no adults }\end{array}$ \\
\hline \multicolumn{3}{|l|}{ Transgenic flies overexpressing B52 } \\
\hline $\begin{array}{l}\text { GMR-GAL4/UAS-B52 } \\
U A S-B 52 /+; s c a-G A L 4 /+\end{array}$ & 22 & $\begin{array}{l}\text { no adult females; rare adult males with weak retina defects } \\
\quad(<1 \% \text { viability) } \\
\text { bristleless adults (>90\% viability) }\end{array}$ \\
\hline \multicolumn{3}{|c|}{ Transgenic flies overexpressing RSF1 and B52 } \\
\hline 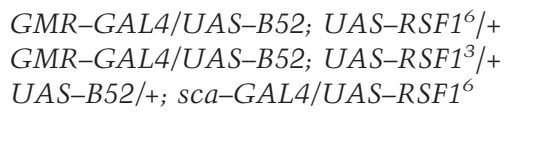 & $\begin{array}{l}22 \\
22 \\
18\end{array}$ & $\begin{array}{l}\text { adults of both sexes with weak retina defects }(\sim 90 \% \text { viability) } \\
\text { adults of both sexes with strong retina defects }(\sim 50 \% \text { viability) } \\
\text { adults with a complete }(\sim 10 \%) \text { or partial set of sensory bristles } \\
(\sim 80 \% \text { viability) }\end{array}$ \\
\hline
\end{tabular}

$\overline{U A S-B 52}$ is a second chromosome insert line from John Lis and colleagues (Kraus and Lis 1994). Most cell lines were provided by the Bloomington Stock Center. The third chromosome sca-GAL4 line was provided by M. Vervoord. The UAS-lacZ insert line is described in Brand et al. (1994).

${ }^{a}$ More than 200 progeny were examined.

GMR-GAL4 (all females died as late pupae) and the rare eclosed males $(<1 \%$ of late male pupae) exhibited a fully penetrant eye phenotype distinct from those observed among the offspring derived from crosses with the various UAS-RSF1 lines (Fig. 7B; Table 1). However, the progeny from the crosses of flies expressing GAL4 from sca enhancers to flies carrying the UAS-B52 element was viable but fails to develop bristles (Fig. 8B; Table 1). Except for a lower viability, this developmental abnormality was very similar to the one caused by RSF1 overexpression driven by sca-GAL4 enhancer (Table 1, UAS$R S F 1^{5} /+$; sca-GAL4/+; Fig. 8B, cf. b and c). Taken together, these data strongly indicate that a normal level of RSF1 or B52/SRp55 protein is critical for viability and normal development of most organs.

Our biochemical data provided evidence for a functional, stoichiometric antagonism between recombinant RSF1 and SR proteins purified from HeLa cells (see above). To test this model in vivo, we asked whether overproduction of RSF1 can rescue some or all of the defects caused by B52/SRp55 overexpression. Transgenic flies carrying both a UAS-B52 and a UAS-RSF1 element were crossed with the GMR-GAL4 transgenic flies. Interestingly, adult progeny of both sexes were obtained, implying that overexpression of RSF1 protein can overcome at least the female lethality and some developmental defects caused by the overexpression of B52/SRp55 protein. A trivial GAL4 dosage effect owing to the presence of two copies of the UAS promoter can be ruled out, because two copies of the UAS-RSF1 elements lead to more deleterious developmental defects than one copy alone (Table 1). The possibility that the overexpression of RSF1 reduces the overexpression of B52/SRp55 can also be discounted, because quantitative reverse transcription (RT)-PCR showed that UAS-B52 mRNA levels, determined at the third-instar larvae, was the same in the progeny overexpressing B52/SRp55 as in the progeny overexpressing B52/SRp55 and RSF1 (Fig. 7C, panel II, cf. lanes 3 and 4). Similar UAS-RSF1 mRNA levels were also observed between progeny overexpressing RSF1 and progeny overexpressing RSF1 and B52/SRp55 (Fig. 7C, panel II, cf. lanes 2 and 4). Furthermore, Western blot analysis using a monoclonal antibody (mAb104) that recognizes several SR protein species (Zahler et al. 1992), defined as SRp20, SRp30a-SRp30b, SRp40, SRp55 (B52), and SRp75, depending on their apparent molecular weight in SDS gels (Fig. 7C, panel III, lane 5), detected a strong band at the level of B52/SRp55 in progeny overexpressing B52/SRp55 (Fig. 7C, panel III, lanes 3,4) but only very little in the progeny that do not (Fig. 7C, panel III, lanes 1,2). The signal of B52/SRp55 did not diminish following overexpression of RSF1 (Fig. 7C, panel III, cf. lanes 3 and 4), confirming that RSF1 has no effect on the expression of B52/SRp55 at the protein level. Given that 
A

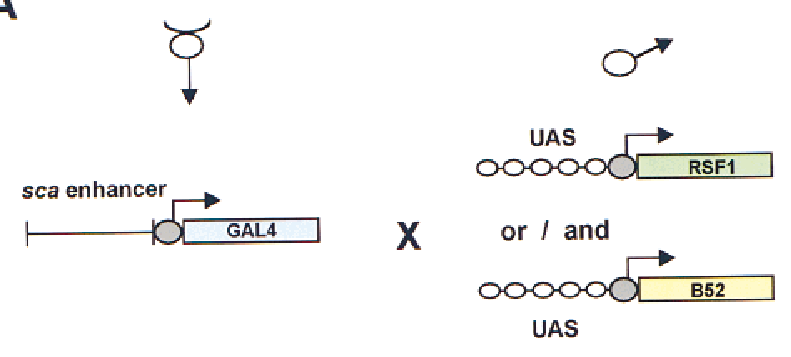

B

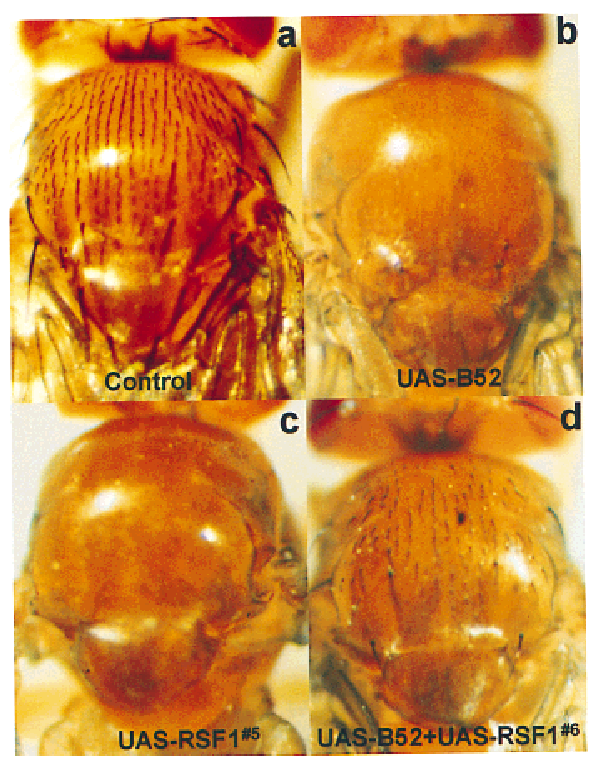

Figure 8. RSF1 functionally antagonizes B52/SRp55 in joint overexpression. $(A)$ Virgin female flies carrying a P element, in which the GAL4-coding sequence was placed under the control of an imaginal disc-specific scabrous ( sca) enhancer, were mated to male flies carrying a single $U A S-B 52$ or $U A S-R S F 1^{5}$ or 6 element or a combination of both. (B) Stereomicroscope views of nota of flies carrying the following genotypes: sca-GAL4/UASlacZ (a), UAS-B52/+; sca-GAL4/+ (b), UAS-RSF1 /+; sca$G A L 4 /+(c)$, and $U A S-B 52 /+; s c a-G A L 4 / U A S-R S F 1^{6}(d)$. All progeny were raised at $18^{\circ} \mathrm{C}$.

mAb104 recognized a phosphoepitope (Roth et al. 1991), it is likely that overexpressed B52/SRp55 is modified by phosphorylation. Thus the rescue of the lethal phenotype could be explained by opposite function of RSF1 and B52/SRp55.

We also analyzed this opposite function when overexpression of RSF1 and B52/SRp55 was driven in another tissue. Although, overexpression of RSF1 under scaGAL4 enhancer (UAS-RSF1\% $/$ sca-GAL4) leads to no adults because of late-purpal stage lethality and overexpression of B52/SRp55 (UAS-B52/+; sca-GAL4/+) leads to bristless adults, the progeny of crosses between $U A S$ $B 52+U A S-R S F 1^{6}$ double element lines and sca-GAL4 transgenic flies were viable and had a complete $(\sim 10 \%$ of the eclosed offspring) or a partial $190 \%$ of the eclosed offspring) stereotyped set of apparently normal sensory bristles (Table 1; Fig. 8B, d). Failure to revert complete bristles phenotypes of all progeny flies $(-10 \%$ had the wild-type phenotype) strongly suggests that the ratio of RSF1 and B52/SRp55 (and/or other SR proteins) may be critical for the normal development of specific organs. Thus, as expected by our model, these in vivo experiments did not reveal functional synergy but rather an antagonism between RSF1 and B52/SRp55; the detrimental effects caused by accumulation of one protein could be partially or fully suppressed by joint accumulation of the other.

\section{Discussion}

RSF1 is a novel splicing regulator that selectively counteracts SR protein function at the earliest steps of spliceosome assembly, preventing the stable binding of $\mathrm{U} 1$ snRNP to pre-mRNA, and thus inactivating $5^{\prime}$ splice-site selection. Such an activity is likely to be relevant in vivo to prevent inappropriate SR protein-dependent activation of cryptic and/or weak $5^{\prime}$ splice sites found near exonic enhancer sequences (Watakabe et al. 1993; Elrick et al. 1998). This fits nicely with the ability of RSF1 to bind enhancer splicing sequences through its RRM (E. Labourier, E. Allemand, S. Brand, M. Fostier, J. Tazi, and H.-M. Bourbon, unpubl.) and to interact via its GRS domain with the RS domain of SR proteins, thereby impairing the formation of productive splicing complexes.

The observation that RSF1 and SR proteins colocalize in the same nuclear regions (data not shown) could be attributed to their participation in similar nuclear events. We present evidence that RSF1 can interact directly with SF2/ASF and that the GRS domain of the former and the RS domain of the latter are required for this interaction. This protein-protein interaction is likely to compete with those occurring between SR proteins and constitutive factors involved in the selection of alternative splice sites. Indeed, SR proteins have been shown to promote the binding of U1 snRNP to the 5' splice site (Eperon et al. 1993; Kohtz et al. 1994; Staknis and Reed 1994; Zahler and Roth 1995), most likely through specific protein-protein interactions between SR proteins and U1-70K (Wu and Maniatis 1993; Kohtz et al. 1994). At least in vitro, we show that RSF1 prevents cooperative interaction between SF2/ASF and U1-snRNP $70 \mathrm{~K}$ protein and thus interferes with the stable binding of U1 snRNP at the 5' splice site. RSF1 may have emerged during evolution as a dominant-negative SR protein that is able to bind negative and/or positive cisacting regulatory sequences preventing activation of nearby weak splice sites. This antagonistic activity differs significantly of that of hnRNP Al whose ratio to SF2/ASF specifies the selection of alternative $5^{\prime}$ splice sites (Mayeda and Krainer 1992) or mutually exclusive exons and modulates exon skipping and inclusion (Mayeda et al. 1993). Although the mechanisms by which hnRNP A1 and SF2/ASF modulate the use of alternative 5 ' splice sites remain poorly understood, it might involve an intrinsic hnRNP Al activity that can facilitate the rapid annealing of complementary RNA molecules that is, between the $5^{\prime}$ end of U1 snRNA and 5' splice site, as well as specific recognition of pre-mRNA se- 
quences via the RRM domains of hnRNP A1 (Mayeda et al. 1994). RSF1 also requires its RRM domain for activity and this domain might even recognize the same sequence as SR proteins but its GRS domain, shown to be essential for splicing repression in vitro, represents a new module acting against the RS domain that has been shown to function as activator of pre-mRNA splicing (Graveley and Maniatis 1998). The modular structure of RSF1 and SR proteins strengthen the correlation between splicing and transcription factors, proposed by Graveley and Maniatis, as both factors contain separable nucleic acid binding and activation or repression domains.

In a given tissue small changes in the RSF1/SR equilibrium could have profound effects on binding site occupancy by either factor and thereby regulate splice-site selection. In this context, it may be relevant that exonic purine-rich sequences have been observed near weak splice sites of many cellular and viral pre-mRNAs that are subject to alternative splicing (Katz and Skalka 1990; Lavigueur et al. 1993; Sun et al. 1993b; Watakabe et al. 1993; Xu et al. 1993; Caputi et al. 1994; Dirksen et al. 1995; Ramchatesingh et al. 1995; Staffa and Cochrane 1995; Staffa et al. 1997). Although in most cases, these elements stimulate splicing of the upstream intron or inclusion of an internal exon, there are exceptions to this rule in which purine-rich elements have been shown to serve as splicing repressors (Kanopka et al. 1996; McNally and McNally 1996). The binding of RSF1 to ESE (E. Labourier, E. Allemand, S. Brand, M. Fostier, J. Tazi, and H.-M. Bourbon, unpubl.) could be a way to mediate splicing repression to prevent activation of cryptic splice sites within large exons. In agreement with this hypothesis, it has been shown recently that RSFc, a protein in the dipteran Chironomus tentans homologous to RSF1, binds extensively to newly transcribed $B R 1$ and $B R 2$ premRNAs, which contain a huge exon 4 of 30-35 kb but much less to the $B R 3$ pre-mRNA, which largely consists of intron sequences (L. Wieslander, pers. comm.).

In vivo experiments are expected to illuminate our findings to provide a rationale to explain how alternative fates of a wide variety of pre-mRNAs can be controlled by a small set of evolutionarily conserved antagonistic sequence-specific splicing factors whose levels or activities may be regulated according to tissue or developmental stages. Consistently, targeted expression in Drosophila of transgenes encoding either the SR protein B52/SRp55 or RSF1 led to pronounced deleterious effects on development (Kraus and Lis 1994; this work). Different severities of phenotype were observed depending on levels of transgene expression, both for B52/SRp55 and for RSF1 (Table 1). Strikingly the effects of the proteins depend on their relative levels as when both proteins were overexpressed in the same tissue the mutant phenotypes were reverted partially or completely. For instance, $>90 \%$ of progeny from crosses between GMRGAL4 and UAS-RSF ${ }^{3}$ or UAS-B52 lines were unable to eclose (Table 1). In sharp contrast, the crosses of transgenic flies carrying both a UAS-B52 and an UAS-RSF1 ${ }^{3}$ element with GMR-GAL4 line led to $50 \%$ viability. Fur- thermore, overexpression of B52/SRp55 restored viability to flies overexpressing RSF1 under the control of another tissue-specific enhancer, the imaginal disc-specific enhancer of the scabrous gene (compare $U A S-R S F 1^{6}$ / sca-GAL4 and UAS-B52/+; sca-GAL4/+ to UAS-B52/ +; sca-GAL4/UAS-RSF1' ${ }^{6}$, implying that B52/SRp55 could have opposing effect to RSF1 in different tissues. These phenotypes cannot be attributed to low levels of expression of either RSF1 or B52/SRp55 mRNAs in the progeny of double-insert lines compared to the progeny of single-insert lines, as these levels were the same (Fig. 7C, panels II, III). Instead, these results support a model in which RSF1 and RSF1-related proteins function as SRprotein antagonists. At this time, we cannot prove that this antagonistic effect is actually a result of competition between a splicing repressor and a splicing activator for the selection of correct splice sites in vivo, although the large body of in vitro work makes this a likely conclusion. By preventing weak and/or cryptic splice sites activation by high levels of SR proteins, RSF1 is expected to restore correct splicing of essential genes for Drosophila development. Therefore, our in vivo work paves the way toward a molecular genetic analysis of the biological role of RSF1, which might allow to uncover factors modifying the activity of RSF1 and SR proteins.

\section{Materials and methods}

\section{Oligonucleotides}

The sequences of the synthetic oligonucleotides (Isoprim SA, Toulouse, France) used in this study as cloning adapters or PCR primers are (sequence is given $5^{\prime} \rightarrow 3^{\prime}$ ) 21Gex, GCAAGCTTGGTGATCAGCGCGGGACAC; F47, CGCCAGGGTTTTCCCAGTCACGAC; ADA1, GATCCCCGGTCAGAATTCAAGCTTATCGATGAGCTCT; ADA2, AGCT-AGAGCTCATCGATAAGCTTGAATTCTGACCGGG; 21H1, CTAGATTAGTTGGCGCTGCTGTGATGATGATGATGATGGCTGCTGCCGAAT; 21H2, CGATTCGGCAGCAGCCATCATCATCATCATCACAGCAGCGCGCCAACTAAT; 21ADA1,GATCTCAAAAGGGCGGCCACGCCAT; 21ADA2, CGATGGCGTGGCCGCCCTTTTGA; 1RBP1, CTTGGATCGCAATCGACATAGG;2RBP1, CACATATGCCGCGATATAGGGAG; HB2T1, GATCCC-GTCGTTGTCGTCGTTGTCGTCGTTGCAAGGGT; HB2T2,CTACCCTTGCAACGACGACAACGACGACAACGACGG; UAS1, GTAACCAGCAACCAAGTAAATCAAC;21F2, TCCCCCTCCAGATCATCCTT; B52A, AACAACCACACCGTTCGCCAAGC; copiaS, GGGCTCTTTTAGCCGAGCAAG; and copiaA, CGCAGCGCCAGTTGCGACG.

\section{Recombinant proteins, plasmids, and purification}

The IPTG-controlled GST expression system (Smith and Johnson 1988) was used to produce RSF1 fusion proteins. A 1.1-kb HindIII-XbaI fragment from pNB21/5.3R [a RSF1 cDNA insert cloned into the pNB40 vector (Brand et al. 1995)] was subcloned into pBluescript II (KS-) between the HindIII and $\mathrm{XbaI}$ sites, to yield the p11HX1 plasmid. The p11HX1 plasmid was in turn used as a template in a PCR with Taq DNA polymerase (Boehringer Mannheim) to amplify the entire RSF1 open reading frame (ORF). A HindIII site was introduced at the $5^{\prime}$ end by using the $21 \mathrm{Gex}$ oligonucleotide and the pBluescript sequencing primer F47. Amplified DNA was cut with HindIII and SacI and inserted into the bacterial GST fusion protein expres- 
sion vector pHBGex between the unique HindIII and SacI sites, to yield the pGex21 expression plasmid. The pHBGex plasmid was derived from pGexA (Valle et al. 1993) by inserting a BamHI-HindIII adaptor made of the two complementary oligonucleotides ADA1 and ADA2 between the BamHI and HindIII sites (note that the original HindIII site has been destroyed). The RSF1 ORF was entirely sequenced to verify its integrity by using a set of synthetic oligonucleotides. To allow for expression of a doubly tagged fusion protein (termed GST-RSF1) with a hexahistidine-based carboxy-terminal affinity tag, a ClaI-XbaI adaptor, made of the two complementary oligonucleotides $21 \mathrm{H} 1$ and $21 \mathrm{H} 2$, was inserted between the unique ClaI and $\mathrm{XbaI}$ sites of pGex21, to yield the pGex21HP1 plasmid. To allow for expression of a doubly tagged fusion protein (termed GST-RSF1 $\Delta$ C) with most of the GRS domain deleted, a BgIII-ClaI adaptor made of the two complementary oligonucleotides 21ADA1 and 21ADA2, was introduced between the unique BglII and ClaI sites of pGex21HP1 (substituting a 360-bp fragment), to yield the pGex21HPN1 plasmid. To allow for expression of a doubly tagged fusion protein (termed GST-RSF1 $\Delta \mathrm{N}$ ) with amino-terminal RRM-containing domain deleted, pGex21HP1 plasmid DNA was cut with EcoRI and BgIII and religated (eliminating a 235-bp fragment) after end filling with the Klenow fragment of E. coli DNA polymerase I and dNTPs, to yield the pGex $21 \mathrm{HPC} 1$ plasmid. The GST-RBP1 fusion was produced from the pGexRBP1 plasmid, which was constructed as follows. The entire coding sequence of $R B P 1$ was PCR amplified from cDNA prepared from poly $(\mathrm{A})^{+}$RNAs extracted from 4- to 8-hr-stage embryos, by using two specific oligonucleotides, termed 1RBP1 and 2RBP1. The resulting 520-bp PCR product was cut with $N d e I$ and EcoRI and inserted into a derivative of pHBGex (H.-M. Bourbon, unpubl.). The RBP1 ORF was entirely sequenced to verify its integrity with respect to the original sequence.

To allow for expression of an hexahistidine-tagged version of the GRS domain of RSF1 (termed RSF1 GRS protein) a 360-bp $\mathrm{NcoI}-\mathrm{XbaI}$ fragment from the $\mathrm{pGex} 21 \mathrm{HP} 1$ plasmid was inserted into the T7-based expression vector pET-14b (Novagen) cut with NcoI and NheI.

To obtain hexahistidine-tagged SF2/ASF proteins, wild-type or truncated versions of SF2/ASF cDNA (provided by J. Manley, Columbia University, New York, NY) were fused in-frame by PCR amplification in pTrcHisA (Invitrogen), using oligonucleotides whose sequences are available upon request (Labourier et al. 1998).

To overexpress GST fusion proteins, BL21 cells (Novagen) freshly transformed with pGex21HP1, pGex21HPN1, pGex21HPC1, pGexRBP1, or pHBGex (as a control) were grown under strong agitation into 2TY medium (16 grams/liter tryptone, 10 grams/liter yeast extract and 5 grams/liter $\mathrm{NaCl}_{\text {; }} \mathrm{pH}$ was adjusted to 7 with $\mathrm{NaOH}$ ) at $37^{\circ} \mathrm{C}$ to an absorbance of 0.8 at $600 \mathrm{~nm}$ in the presence of $100 \mathrm{\mu g} / \mathrm{ml}$ ampicillin. Isopropyl- $\beta$-dTHIOGALACTOPYRANOSIDE (IPTG) WAS ADDED TO 1 MM and incubation was continued for an additional $3 \mathrm{hr}$. Bacteria were harvested, frozen in dry ice for $30 \mathrm{~min}$, stored at $-80^{\circ} \mathrm{C}$, partially thawed on ice $(\sim 15 \mathrm{~min})$, and quickly resuspended in one-fifth volume of MTPBS (150 mM NaCl, $16 \mathrm{~mm} \mathrm{Na}_{2} \mathrm{HPO}_{4}$ and $4 \mathrm{~mm}$ $\mathrm{NaH}_{2} \mathrm{PO}_{4} ; \mathrm{pH}$ was adjusted to 7 with $\mathrm{NaOH}$ ). All subsequent steps were carried out at $4^{\circ} \mathrm{C}$. One-tenth volume of a freshly made $10 \mathrm{mg} / \mathrm{ml}$ lysozyme (Sigma) solution was added. After a 30-min incubation, cells were harvested by centrifugation (5000 $\mathrm{rpm}$ in an SS-34 Sorvall rotor for $5 \mathrm{~min}$ at $4^{\circ} \mathrm{C}$ ). The cell pellet was resuspended in the same volume of MTPBS supplemented with $10 \mathrm{~mm}$ dithiothreitol (DTT; Sigma) and 1\% Tween 20 (BioRad). One-milliliter aliquots were subjected to sonication at $4^{\circ} \mathrm{C}$ until the viscosity was reduced to that of buffer, and lysates were incubated on ice for $1 \mathrm{hr}$. The bacterial debris and in- soluble materials were removed by centrifugation $(12,000 \mathrm{rpm}$ in a microcentrifuge for $5 \mathrm{~min}$ at $4^{\circ} \mathrm{C}$ ), and supernatants were frozen in dry ice and stored at $-80^{\circ} \mathrm{C}$. Supernatants were thawed on ice and incubated for $30 \mathrm{~min}$ with one-twentieth volume of a $50 \%$ glutathione-Sepharose bead suspension (Pharmacia) equilibrated in MTPBS. The beads were pelleted and the same volume of the $50 \%$ bead suspension was added to the supernatant and incubated as above. Both sets of beads were mixed and washed three times with 10-bed volumes of MTPBS. GST or fusion proteins were eluted off the beads by two washes with two bead volumes of $20 \mathrm{~mm}$ reduced glutathione (Sigma) in 120 $\mathrm{mm} \mathrm{KCl}$ and $100 \mathrm{~mm}$ Tris- $\mathrm{HCl}$ at $\mathrm{pH}$ 7. Aliquots of purified proteins were stored at $-80^{\circ} \mathrm{C}$.

His-tagged recombinant proteins were expressed in TG1 (SF2/ ASF, SF2/ASF $\triangle$ RS, and SF2/ASF RS) or BL21 (RSF1 GRS) bacteria and purified from inclusion bodies as described (Labourier et al. 1998).

Total SR proteins and SRp30 protein were purified from HeLa cells or calf thymus as described (Zahler et al. 1992). Purified U1 snRNP from HeLa cells was provided by R. Lührmann (Philips University, Marburg, Germany).

In vitro transcription, splicing assays, gel filtration, and U1 snRNP-pre-mRNA binding experiments

Radiolabeled RNAs were synthesized by in vitro transcription in presence of 20 units of SP6 RNA polymerase (Boehringer), 1 $\mu \mathrm{g}$ of the suitable linearized plasmids, and $5 \mu \mathrm{M}\left[\alpha{ }^{-32} \mathrm{P}\right] \mathrm{UTP}$ (400 $\mathrm{Ci} / \mathrm{mmole}$ ) in $25-\mu 1$ reactions according to the manufacturers. All in vitro transcripts were purified by denaturing polyacrylamide-urea gels and quantitated by Cerenkov counting.

The single-intron human $\beta$-globin construct pSPH $\beta$-3A was derived from pSP64H $\beta \Delta 6$ (Krainer et al. 1984) by inserting the HB2T1/HB2T2 AccI-BamHI adapter between the AccI (in the second exon) and BamHI (from pSP64) sites. The splicing reactions were done under standard conditions for $1.5 \mathrm{hr}$ in a total volume of $20 \mu \mathrm{l}$ containing 50-fmole labeled pre-mRNA and $6 \mu \mathrm{l}$ of HeLa nuclear extract (Dignam et al. 1983) complemented with buffer D. Purified proteins diluted in buffer D were incubated in HeLa nuclear extract for $5 \mathrm{~min}$ at room temperature before addition of radiolabeled pre-mRNA. Splicing products were analyzed by electrophoresis on denaturing $7 \%$ (Fig. 2A) or $6 \%$ (Fig. 2B) polyacrylamide gels and revealed by autoradiography.

Gel-filtration chromatography was done essentially as described previously (Michaud and Reed 1991; Staknis and Reed 1994). Complex assembly reactions were incubated for $30 \mathrm{~min}$ at $30^{\circ} \mathrm{C}$ in a total volume of $250 \mu \mathrm{l}$ containing $75 \mu \mathrm{l}$ of $\mathrm{HeLa}$ nuclear extract (Dignam et al. 1983), 1-pmole labeled premRNA, and either purified SRp30 (3.5 $\mu \mathrm{l}, 210$ pmole) or GSTRSF1 ( $20 \mu \mathrm{l}, 260$ pmoles). Reactions were then applied to a $2.5 \times 60$-cm column filled with Sephacryl S-500 equilibrated in buffer D (Dignam et al. 1983), and 2-ml fractions were collected at a flow rate of $2 \mathrm{ml} / \mathrm{hr}$ for Cerenkov counting.

SF2/ASF and U1 snRNP complex formation assays were performed as described previously (Kohtz et al. 1994) in $20 \mathrm{~mm}$ HEPES at $\mathrm{pH} 7.6,5 \%$ glycerol, $100 \mathrm{~mm} \mathrm{KCl}, 0.2 \mathrm{~mm}$ EDTA, and $1.5 \mathrm{mM} \mathrm{MgCl}_{2}$. Before loading half of the mixtures onto native gels, heparin and glycerol were added to a final concentration of $1 \mathrm{mg} / \mathrm{ml}$ and $15 \%$, respectively.

\section{Protein-protein interaction studies}

For GST-binding assays, purified GST-RSF1 or GST-RSF1 $\Delta \mathrm{C}$ (150 pmoles each) were bound to $20 \mu \mathrm{l}$ of glutathione-Sepharose beads in buffer $\mathrm{D}$ for $15 \mathrm{~min}$ at room temperature. After two 
washes with buffer $\mathrm{D}$, beads were then incubated with an excess of SF2/ASF RS or RSF1 GRS protein (300 pmoles each) for 30 min at room temperature and washed extensively with buffer $D$. Proteins were eluted by boiling for $5 \mathrm{~min}$ in SDS-loading buffer and analyzed on a $12 \%$ SDS-polyacrylamide gel. Proteins were revealed by Coomassie blue staining.

For Far-Western analysis, purified recombinant proteins $\mid \sim 1$ $\mu \mathrm{g}$ of each), HeLa purified SR proteins ( $2 \mu \mathrm{g}$ ) previously treated with 50 units of calf intestinal alkaline phosphatase for $1 \mathrm{hr}$ at $30^{\circ} \mathrm{C}$ (to dephosphorylate them and improve their detection by labeled probes), or purified U1 snRNP $(3 \mu \mathrm{g})$ were run on a $12 \%$ SDS-polyacrylamide gel and transferred to nitrocellulose by electroblotting for $90 \mathrm{~min}$ in $10 \mathrm{~mm}$ CAPS transfer buffer at $\mathrm{pH}$ 11.0 , containing $10 \%$ methanol. To renature the proteins, the filters were treated as described previously (Kohtz et al. 1994) and probed with $10 \mu \mathrm{g}$ of labeled SF2/ASF or GST-RSF1 in 10 $\mathrm{ml}$ of binding buffer (Kohtz et al. 1994). To label SF2/ASF and GST-RSF1, $10 \mu \mathrm{g}$ of each purified recombinant protein was incubated with 800 units of purified starfish cdc2 protein kinase (a generous gift from M. Dorée laboratory, CNRS, Montpelier, France) in the presence of $20 \mu \mathrm{Ci}$ of $\left[\gamma^{32}{ }^{32} \mathrm{P}\right] \mathrm{ATP}$ and $1 \mu \mathrm{M}$ of cold ATP in buffer B (Labourier et al. 1998) for $1 \mathrm{hr}$ at $30^{\circ} \mathrm{C}$. Unreacted nucleotides and cdc2 kinase were removed by binding labeled SF2/ASF or GST-RSF1 to nickel-agarose beads or glutathione-Sepharose beads, respectively. After extensive washings of the beads with buffer $\mathrm{B}$, labeled proteins were eluted with either $1 \mathrm{M}$ imidazole for SF2/ASF or $20 \mathrm{~mm}$ glutathione for GST-RSF1.

\section{Drosophila stocks}

The UAS-RSF1 construct was made as follows: a 1.15-kb XbaIXhoI RSF1 cDNA fragment, prepared from p11HX1 (see above), was subcloned into the $X$ hoI and $X b a I$ sites of the pUAST vector (Brand et al. 1994). This pUAST-RSF1 DNA was used to transform $w^{1118}$ flies according to standard protocols (Spradling and Rubin 1982), except that injections employed nondechorionated embryos. Fifteen independent UAS-RSF1 transgenic lines were established. The transposon integration sites were mapped to individual chromosomes by standard crosses using balancer stocks. Three homozygous viable lines $(3,5$, and 6$)$ were used in this report. These transformed flies were crossed to homozygous (GMR-GAL4, sca-GAL4, or da-GAL4) GAL4-expressing lines and scored for phenotypes under a stereomicroscope. Most GAL4 lines were from the Bloomington Stock Center. The scaGAL4 line (Y.N. Jan, unpubl.) was provided by M. Vervoord (CNRS, Toulouse, France). All flies were reared at $18-28^{\circ} \mathrm{C}$ on standard medium. Homozygous double insert lines were obtained by standard crosses using balancer stocks.

\section{Determination of UAS-RSF1, UAS-B52 transgene expression} and developmental Northern blot analysis

Total RNAs or proteins were purified from 20 larvae of the following genotypes: (GMR-GAL4/+; UAS-lacZ/+), (GMRGAL4/+; UAS-RSF1 $\left.{ }^{3} /+\right),(G M R-G A L 4 / U A S-B 52)$ and (GMRGAL4/UAS-B52; UAS-RSF1 ${ }^{3} /+$ ) with $1 \mathrm{ml}$ of Trizol reagent (GIBCO-BRL). RNAs were treated subsequently with 2 units of RQ1 DNase (Promega) for $15 \mathrm{~min}$ at $34^{\circ} \mathrm{C}$ and quantitated by UV absorbance determination. Reverse transcriptions were carried out with 400 units of M-MLV reverse transcriptase (GIBCO-BRL), $5 \mu \mathrm{g}$ of total RNA, and $350 \mu \mathrm{g}$ of poly(dT) 15 primer in a final volume of $50 \mu \mathrm{l}$. PCRs were performed with $1.25,2.5$, or $5 \mu \mathrm{l}$ of the RT reactions, 20 pmole of each primer (UAS1 and 21F2 for UAS-RSF1, UAS1 and B52A for UAS-B52, copiaS and copiaA for the Drosophila retrotransposon copia),
$100 \mu \mathrm{M}$ dNTP, $1 \mathrm{~mm} \mathrm{MgCl}_{2}, 2.5$ units of Taq DNA polymerase (GIBCO-BRL), and $2 \mu \mathrm{Ci}\left[\mu^{-32} \mathrm{P}\right] \mathrm{dCTP}$ in a final volume of $50 \mu \mathrm{l}$. After 20 cycles of PCR $\left(30 \mathrm{sec}\right.$ at $60^{\circ} \mathrm{C}, 1 \mathrm{~min}$ at $72^{\circ} \mathrm{C}, 30 \mathrm{sec}$ at $\left.95^{\circ} \mathrm{C}\right), 2 \mu \mathrm{l}$ of each PCR reaction was boiled for $3 \mathrm{~min}$, loaded onto a $5 \%$ denaturing polyacrylamide gel, and amplified fragments were revealed by autoradiography.

Total proteins from transgenic larvae or HeLa nuclear extract $(\sim 30 \mu \mathrm{g})$ were run on $12 \%$ SDS-polyacrylamide gels and transferred to nitrocellulose by electroblotting for $90 \mathrm{~min}$ in $10 \mathrm{~mm}$ CAPS transfer buffer (pH 11.0), containing 10\% methanol. Blots were probed with mAb104 (Roth et al. 1991). A horseradish peroxidase-conjugated anti-mouse IgM (Sigma) and the ECL reagent (Amersham) were used for visualization of mAb104-reactive proteins.

Northern blot analysis was done as described (Brand and Bourbon 1993) using the largest RSF1 cDNA insert (Brand et al. 1995) as a probe.

\section{Acknowledgments}

We are grateful to J. Steitz for helpful comments on the manuscript. We thank J. Lis, M. Vervood, and the Bloomington Stock Center for fly strains, R. Lührmann for purified U1 snRNP and PIP7 constructs, M. Dorée for purified cdc2 kinase, J. Stèvenin for HeLa-purified SR proteins, J. Manley for SF2/ASF cDNA, and A. Krainer for providing pSP $64 \mathrm{H} \beta \Delta 6$ construct. H.-M.B. acknowledges F. Amalric and A. Vincent for their interest as well as logistical support in the initial part of this work. We thank D. Cribbs for support, scientific interest, and critical review of the manuscript. A special thanks to A.-M. Duprat for her constant support. We also thank Y. De Preval for synthesizing a number of oligonucleotides and, C. Ardourel and A. Lepage for help in injection of embryos. This work was supported by an Action Thématique Incitative sur Programme et Equipes (ATIPE) grant from the CNRS (to H.-M.B.) and a grant from the CNRS and the Association pour le Recherche sur le Cancer (ARC) (to J.T.). E.L and E.A. were supported by graduate fellowships from the Ministere de 1' Enseignement Superieur et de la Recherche (MESR); E.L. and I.G. benefited from a graduate training fellowship from the ARC and Foundation pour le Recherche Médicale (FRM), respectively.

The publication costs of this article were defrayed in part by payment of page charges. This article must therefore be hereby marked 'advertisement' in accordance with 18 USC section 1734 solely to indicate this fact.

\section{References}

Adams, M.D., D.Z. Rudner, and D.C. Rio. 1996. Biochemistry and regulation of pre-mRNA splicing. Curr. Opin. Cell. Biol. 8: 331-339.

Amrein, H., M.L. Hedley, and T. Maniatis. 1994. The role of specific protein-RNA and protein-protein interactions in positive and negative control of pre-mRNA splicing by transformer 2. Cell 76: 735-746.

Ayane, M., U. Preuss, G. Kohler, and P.J. Nielsen. 1991. A differentially expressed murine RNA encoding a protein with similarities to two types of nucleic acid binding motifs. Nucleic Acids Res. 19: 1273-1278.

Berget, S.M. 1995. Exon recognition in vertebrate splicing. $J$. Biol. Chem. 270: 2411-2414.

Brand, S. and H.-M. Bourbon. 1993. The developmentally-regulated Drosophila gene rox8 encodes an RRM-type RNA binding protein structurally related to human TIA-1-type nucleolysins. Nucleic Acids Res. 21: 3699-3704. 
Brand, A.H., A.S. Manoukian, and N. Perrimon. 1994. Ectopic expression in Drosophila. Methods Cell Biol. 44: 635-654.

Brand, S.F., S. Pichoff, S. Noselli, and H.-M. Bourbon. 1995. Novel Drosophila melanogaster genes encoding RRM-type RNA-binding proteins identified by a degenerate PCR strategy. Gene 154: 187-192.

Càceres, J.F. and A.R. Krainer. 1993. Functional analysis of premRNA splicing factor SF2/ASF structural domains. EMBO J. 12: 4715-4726.

Càceres, J.F., S. Stamm, D.M. Helfman, and A.R. Krainer. 1994. Regulation of alternative splicing in vivo by overexpression of antagonistic splicing factors. Science 265: 1706-1709.

Caputi, M., G. Casari, S. Guenzi, R. Tagliabue, A. Sidoli, C.A. Melo, and F.E. Baralle. 1994. A novel bipartite splicing enhancer modulates the differential processing of the human fibronectin EDA exon. Nucleic Acids Res. 22: 1018-1022.

Cavaloc, Y., M. Popielarz, J.P. Fuchs, R. Gattoni, and J. Stèvenin. 1994. Characterisation and cloning of the human splicing factor 9G8: a novel $35 \mathrm{kDa}$ factor of the serine/ arginine protein family. EMBO J. 13: 2639-2649.

Champlin, D.T., M. Frash, H. Saumweber, and J.T. Lis. 1991. Characterization of a Drosophila protein associated with boundaries of transcriptionally active chromatin. Genes \& Dev. 51611-1621.

Dignam, J.D., R.M. Lebovitz, and R.G. Roeder. 1983. Accurate transcription initiation by RNA polymerase II in a soluble extract from isolated mammalian nuclei. Nucleic Acids Res. 11: $1475-1489$.

Dirksen, W.P., R.K. Hampson, Q. Sun, and F.M. Rottman. 1994. A purine-rich exon sequence enhances alternative splicing of bovine growth hormone pre-mRNA. J. Biol. Chem. 269: 6431-6436.

Dirksen, W.P., Q. Sun, and F.M. Rottman. 1995. Multiple splicing signals control alternative intron retention of bovine growth hormone pre-mRNA. J. Biol. Chem. 270: 5346-5352.

Elrick, L.L., M.B. Humphrey, T.A. Cooper, and S.M. Berget. 1998. A short sequence within two purine-rich enhancers determines 5' splice site specificity. Mol. Cell. Biol. 18: 343 352.

Eperon, I.C., D.C. Ireland, R.A. Smith, A. Mayeda, and A.R. Krainer. 1993. Pathways for selection of 5 ' splice sites by U1 snRNPs and SF2/ASF. EMBO J. 12: 3607-3617.

Freeman, M. 1996. Reiterative use of EGF receptor triggers differentiation of all cell types in the Drosophila eye. Cell 87: 651-660.

Fu, X.D. 1995. The superfamily of arginine/serine-rich splicing factors. RNA 1: 663-680.

Ge, H. and J.L. Manley. 1990. A protein factor, ASF, controls cell-specific alternative splicing of SV40 early pre-mRNA in vitro. Cell 62: 25-34.

Ge, H., P. Zuo, and J.L. Manley. 1991. Primary structure of the human splicing factor ASF reveals similarities with Drosophila regulators. Cell 66: 373-382.

Graveley, B.R. and T. Maniatis. 1998. Arginine/serine-rich domains of SR proteins can function as activators of premRNA splicing. Mol. Cell 1: 765-771.

Green, M.R. 1991. Biochemical mechanisms of constitutive and regulated pre-mRNA splicing. Annu. Rev. Cell. Biol. 7: 559599 .

Jamison, S.F., A. Crow, and M.A. Garcia-Blanco. 1992. The spliceosome assembly pathway in mammalian extracts. Mol. Cell. Biol. 12: 4279-4287.

Jamison, S.F., Z. Pasman, J. Wang, C. Will, R. Lührmann, J.L. Manley, and M.A. Garcia-Blanco. 1995. U1 snRNP-ASF/SF2 interaction and $5^{\prime}$ splice site recognition: Characterization of required elements. Nucleic Acids Res. 23: 3260-3267.
Kanopka, A., O. Muhlemann, and G. Akusjarvi. 1996. Inhibition by SR proteins of splicing of a regulated adenovirus pre-mRNA. Nature 381: 535-538.

Katz, R.A. and A.M. Skalka. 1990. Control of retroviral RNA splicing through maintenance of suboptimal processing signals. Mol. Cell. Biol. 10: 696-704.

Kim, Y.-J., P. Zuo, J.L. Manley, and B.S. Baker. 1992. The Drosophila RNA binding protein RBP1 is localized to transcriptionally active sites of chromosomes and shows a functional similarity to human splicing factor ASF/SF2. Genes \& Dev. 6: 2569-2579.

Kohtz, J.D., S.F. Jamison, C.L. Will, P. Zuo, R. Lührmann, M.A. Garcia-Blanco, and J.L. Manley. 1994. Protein-protein interactions and $5^{\prime}$-splice-site recognition in mammalian mRNA precursors. Nature 368: 119-124.

Krainer, A.R., T. Maniatis, B. Ruskin, and M.R. Green. 1984. Normal and mutant human $\beta$-globin pre-mRNAs are faithfully and efficiently spliced in vitro. Cell 36: 993-1005.

Krainer, A.R., G.C. Conway, and D. Kozak. 1990. The essential pre-mRNA splicing factor SF2 influences 5' splice site selection by activating proximal sites. Cell 62: 35-42.

Krainer, A.R., A. Mayeda, D. Kozak, and G. Binns. 1991. Functional expression of cloned human splicing factor SF2: Homology to RNA-binding proteins, U1 70K, and Drosophila splicing regulators. Cell 66: 383-394.

Kraus, M.E. and J.T. Lis. 1994. The concentration of B52, an essential splicing factor and regulator of splice site choice in vitro, is critical for Drosophila development. Mol. Cell. Biol. 14: 5360-5370.

Krämer, A. 1996. The sructure and function of proteins involved in mammalian pre-mRNA splicing. Annu. Rev. Biochem. 65: 367-409.

Labourier, E., F. Rossi, I.E. Gallouzi, E. Allemand, G. Divita, and J. Tazi. 1998. Interaction between the N-terminal domain of human DNA topoisomerase I and the arginine-serine domain of its substrate determines phosphorylation of SF2/ ASF splicing factor. Nucleic Acids Res. 26: 2955-2962.

Lavigueur, A., H. La Branche, A.R. Kornblihtt, and B. Chabot. 1993. A splicing enhancer in the human fibronectin alternate ED1 exon interacts with SR proteins and stimulates U2 snRNP binding. Genes \& Dev. 7: 2405-2417.

Liu, H.X., M. Zhang, and A.R. Krainer. 1998. Identification of functional exonic splicing enhancer motifs recognized by individual SR proteins. Genes \& Dev. 12: 1998-2012.

Lynch, K.W. and T. Maniatis. 1995. Synergistic interactions between two distinct elements of a regulated splicing enhancer. Genes \& Dev. 9: 284-293.

Lynch, K.W. and T. Maniatis. 1996. Assembly of specific SR protein complexes on distinct regulatory elements of the Drosophila doublesex splicing enhancer. Genes \& Dev. 10: 2089-2101.

Manley, J.L. and R. Tacke. 1996. SR proteins and splicing control. Genes \& Dev. 10: 1569-1579.

Mayeda, A. and A.R. Krainer. 1992. Regulation of alternative pre-mRNA splicing by hnRNP A1 and splicing factor SF2. Cell 68: 365-375.

Mayeda, A., A.M. Zahler, A.R. Krainer, and M.B. Roth. 1992. Two members of a conserved family of nuclear phosphoproteins are involved in pre-mRNA splicing. Proc. Natl. Acad. Sci. 89: 1301-1304.

Mayeda, A., D.M. Helfman, and A.R. Krainer. 1993. Modulation of exon skipping and inclusion by heterogeneous nuclear ribonucleoprotein A1 and pre-mRNA splicing factor SF2/ ASF [published erratum appears in Mol. Cell. Biol. 1993 13: 4458]. Mol. Cell. Biol. 13: 2993-3001.

Mayeda, A., S.H. Munroe, J.F. Caceres, and A.R. Krainer. 1994. 
Function of conserved domains of hnRNP A1 and other hnRNP A/B proteins. EMBO J. 13: 5483-5495.

McNally, L.M. and M.T. McNally. 1996. SR protein splicing factors interact with the Rous sarcoma virus negative regulator of splicing element. J. Virol. 70: 1163-1172.

Michaud, S. and R. Reed. 1991. An ATP-independent complex commits pre-mRNA to the mammalian spliceosome assembly pathway. Genes \& Dev. 5: 2534-2546.

Michaud, S. and R. Reed. 1993. A functional association between the $5^{\prime}$ and $3^{\prime}$ splice sites is established in the earliest prespliceosome complex (E) in mammals. Genes \& Dev. 7: 1008-1020.

Noselli, S. and A. Vincent. 1992. The Drosophila melanogaster ribosomal protein L17A-encoding gene. Gene 118: 273-278.

Ramchatesingh, J., A.M. Zahler, K.M. Neugebauer, M.B. Roth, and T.A. Cooper. 1995. A subset of SR proteins activates splicing of the cardiac troponin $\mathrm{T}$ alternative exon by direct interactions with an exonic enhancer. Mol. Cell. Biol. 15: 4898-4907.

Reed, R. 1996. Initial splice-site recognition and pairing during pre-mRNA splicing. Curr. Opin. Genet. \& Dev. 6: 215-220.

Ring, H.Z. and J.T. Lis. 1994. The SR protein B52/SRp55 is essential for Drosophila development. Mol. Cell. Biol. 14: 7499-7506.

Roth, M.B., A.M. Zahler, and J.A. Stolk. 1991. A conserved family of nuclear phosphoproteins localized to sites of RNA polymerase II transcription. I. Cell. Biol. 115: 587-596.

Ruskin, B., P.D. Zamore, and M.R. Green. 1988. A factor, U2AF, is required for $\mathrm{U} 2$ snRNP binding and splicing complex assembly. Cell 52: 207-219.

Sharp, P.A. 1994. Split genes and RNA splicing. Cell 77: 805815.

Smith, D.B. and K.S. Johnson. 1988. Single-step purification of polypeptides expressed in Escherichia coli as fusions with glutathione S-transferase. Gene 67: 31-40.

Spradling, A.C. and G.M. Rubin. 1982. Transposition of cloned P elements into Drosophila germ line chromosomes. Science 218: 341-347.

Staffa, A. and A. Cochrane. 1995. Identification of positive and negative splicing regulatory elements within the terminal tat-rev exon of human immunodeficiency virus type 1. Mol. Cell. Biol. 15: 4597-4605.

Staffa, A., N.H. Acheson, and A. Cochrane. 1997. Novel exonic elements that modulate splicing of the human fibronectin EDA exon. J. Biol. Chem. 272: 33394-33401.

Staknis, D. and R. Reed. 1994. SR proteins promote the first specific recognition of pre-mRNA and are present together with the U1 small nuclear ribonucleoprotein particle in a general splicing enhancer complex. Mol. Cell. Biol. 14: $7670-7682$.

Staley, J.P. and C. Guthrie. 1998. Mechanical devices of the spliceosome: Motors, clocks, springs, and things. Cell 92: 315-326.

Sun, Q., R.K. Hampson, and F.M. Rottman. 1993a. In vitro analysis of bovine growth hormone pre-mRNA alternative splicing. Involvement of exon sequences and trans-acting factor(s). J. Biol. Chem. 268: 15659-15666.

Sun, Q., A. Mayeda, R.K. Hampson, A.R. Krainer, and F.M. Rottman. 1993b. General splicing factor SF2/ASF promotes alternative splicing by binding to an exonic splicing enhancer. Genes \& Dev. 7: 2598-2608.

Tanaka, K., A. Watakabe, and Y. Shimura. 1994. Polypurine sequences within a downstream exon function as a splicing enhancer. Mol. Cell. Biol. 14: 1347-1354.

Tian, M. and T. Maniatis. 1993. A splicing enhancer complex controls alternative splicing of doublesex pre-mRNA. Cell
74: $105-114$

Valle, D., J. Kun, J. Linss, E.D. Garcia, S, and S. Goldenberg. 1993. cDNA cloning and expression of Rhodnius prolixus vitellogenin. Insect Biochem. Mol. Biol. 23: 457-465.

Vellard, M., J. Soret, A. Sureau, and B. Perbal. 1992. A novel type of RNA-binding protein is potentially encoded by the opposite strand of the trans-spliced c-myb coding exon. Proc. Natl. Acad. Sci. 89: 2511-2515.

Wang, J. and J.L. Manley. 1997. Regulation of pre-mRNA splicing in metazoa. Curr. Opin. Genet. \& Dev. 7: 205-211.

Wang, J., Y. Takagaki, and J.L. Manley. 1996. Targeted disruption of an essential vertebrate gene: ASF/SF2 is required for cell viability. Genes \& Dev. 10: 2588-2599.

Wang, J., S.H. Xiao, and J.L. Manley. 1998. Genetic analysis of the SR protein ASF/SF2: Interchangeability of RS domains and negative control of splicing. Genes \& Dev. 12: 22222233.

Watakabe, A., K. Tanaka, and Y. Shimura. 1993. The role of exon sequences in splice site selection. Genes \& Dev. 7: 407-418.

Wu, J.Y. and T. Maniatis. 1993. Specific interactions between proteins implicated in splice site selection and regulated alternative splicing. Cell 75: 1061-1070.

$\mathrm{Xu}, \mathrm{R} ., \mathrm{J}$. Teng, and T.A. Cooper. 1993. The cardiac troponin T alternative exon contains a novel purine-rich positive splicing element. Mol. Cell. Biol. 13: 3660-3674.

Zahler, A.M. and M.B. Roth. 1995. Distinct functions of SR proteins in recruitment of U1 small nuclear ribonucleoprotein to alternative $5^{\prime}$ splice sites. Proc. Natl. Acad. Sci. 92: 2642-2646.

Zahler, A.M., W.S. Lane, J.A. Stolk, and M.B. Roth. 1992. SR proteins: A conserved family of pre-mRNA splicing factors. Genes \& Dev. 6: 837-847.

Zahler, A.M., K.M. Neugebauer, W.S. Lane, and M.B. Roth. 1993. Distinct functions of SR proteins in alternative premRNA splicing. Science 260: 219-222.

Zamore, P.D. and M.R. Green. 1989. Identification, purification, and biochemical characterization of U2 small nuclear ribonucleoprotein auxiliary factor. Proc. Natl. Acad. Sci. 86: $9243-9247$.

Zamore, P.D., J.G. Patton, and M.R. Green. 1992. Cloning and domain structure of the mammalian splicing factor U2AF. Nature 355: 609-614.

Zuo, P. and J.L. Manley. 1993. Functional domains of the human splicing factor ASF/SF2. EMBO J. 12: 4727-4737.

Zuo, P. and T. Maniatis. 1996. The splicing factor U2AF35 mediates critical protein-protein interactions in constitutive and enhancer-dependent splicing. Genes \& Dev. 10: 13561368 . 


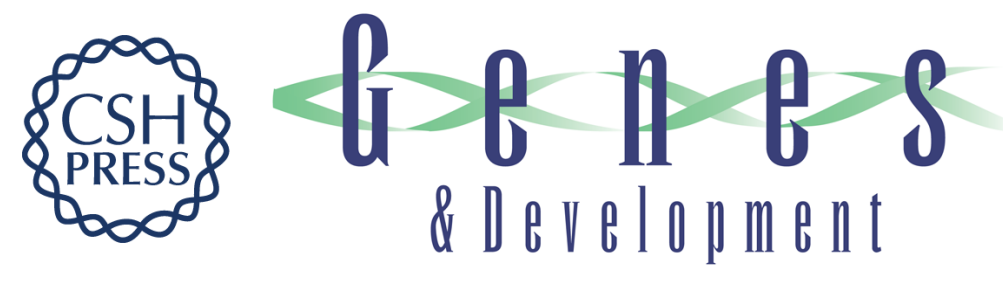

\section{Antagonism between RSF1 and SR proteins for both splice-site recognition in vitro and Drosophila development}

Emmanuel Labourier, Henri-Marc Bourbon, Imed-eddine Gallouzi, et al.

Genes Dev. 1999, 13:

References This article cites 79 articles, 39 of which can be accessed free at:

http://genesdev.cshlp.org/content/13/6/740.full.html\#ref-list-1

License

Email Alerting Receive free email alerts when new articles cite this article - sign up in the box at the top Service right corner of the article or click here.

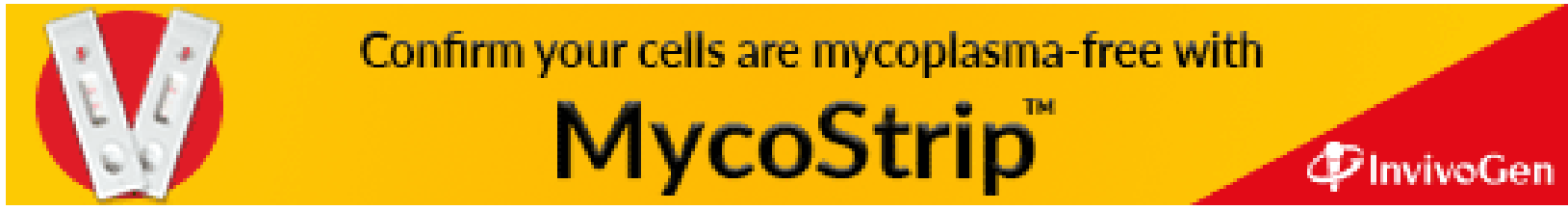

